\title{
Analysis of a Three-Phase Grid-Connected PV Power System Using a Modified Dual-Stage Inverter
}

\author{
Denizar Cruz Martins \\ Department of Electrical Engineering, Power Electronics Institute, Federal University of Santa Catarina, P. O. Box 5119, \\ 88040-970 Florianopolis, SC, Brazil \\ Correspondence should be addressed to Denizar Cruz Martins; denizar@inep.ufsc.br
}

Received 30 August 2012; Accepted 18 September 2012

Academic Editors: A. Bosio and L. Ozgener

Copyright (C) 2013 Denizar Cruz Martins. This is an open access article distributed under the Creative Commons Attribution License, which permits unrestricted use, distribution, and reproduction in any medium, provided the original work is properly cited.

\begin{abstract}
This paper presents a grid-connected PV system in a centralized configuration constructed through a three-phase dual-stage inverter. For the DC-DC stage the three-phase series resonant converter is chosen thanks to the advantages that it exhibits. However, it is inadequate for the accomplishment of MPPT, due to its efficiency strongly depending on the implemented deadtime and switching frequency. Then, this paper proposes a conceptual modification, that is, a modified dual-stage inverter in which the inverter stage is responsible for both the MPPT and the grid-current control. In addition, the DC-DC converter operates with constant duty cycle and frequency. Such configuration requires a new concept, introduced as Behavior Matching. It serves as a fundamental feature for the DC-DC converter to reproduce the PV array $I-V$ characteristic when they are connected, without control action. The maximum power operating point is found by maximizing the direct axis current, obtained by Park's transformation from the inverter, through the perturbation and observation algorithm. Any specific measurement to realize the MPPT is needed. The galvanic isolation is achieved by using a high-frequency transformer. The structure is appropriate for high power applications, above $10 \mathrm{~kW}$.
\end{abstract}

\section{Introduction}

The photovoltaic solar energy represents an emergent technology in function of the continuous fall in the production costs and in the technological progress of the PV modules. This alternative energy can significantly contribute with the reduction in the emission of greenhouse gases in the atmosphere, which attack the environment deeply.

Around $75 \%$ of the PV systems installed in the world are grid connected [1]. In the grid-connected PV system, DC-AC converters (inverters) need to realize the grid interconnection, inverting the dc current that comes from the PV array into a sinusoidal waveform synchronized with the utility grid $[2,3]$. Besides, the DC-AC converter is used to stabilize the dc-bus voltage to a specific value, because the output voltage of the PV array varies with temperature, irradiance, and the effect of MPPT (maximum power point tracking) [4-23]. The DC-AC conversion systems, depending on its topology, can be classified as presented as follows $[24,25]$. (i) Single-stage inverter: in one processing stage, MPPT and grid-current control are handled (Figure 1).

(ii) Dual-stage inverter: a DC-DC converter performs the MPPT and a DC-AC one is responsible for the gridcurrent controlling (Figure 2).

(iii) Multistage inverter: various DC-DC converters are used for the MPPT and only one DC-AC converter takes care of the grid-current control (Figure 3).

The inverters previously shown give an idea about the control and the DC-DC converters' application. It is worth to discuss in more details how the PV modules are connected with inverters and these are connected with the grid. There are four configurations commercially accepted [26-30].

(i) Central-plant inverter: usually a large inverter is used to convert DC output power of the PV array to AC power. In this system, the PV modules are serially string and several strings are connected in parallel to 


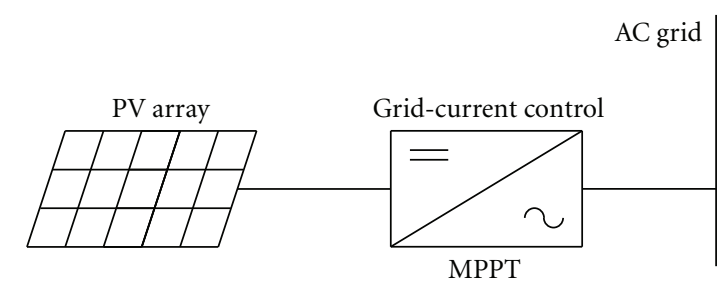

FIGURE 1: Single-stage inverter without a DC-DC converter.

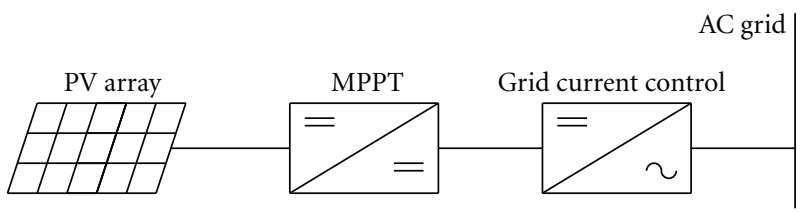

Figure 2: Photovoltaic solar energy flowing through two conditioning converters.

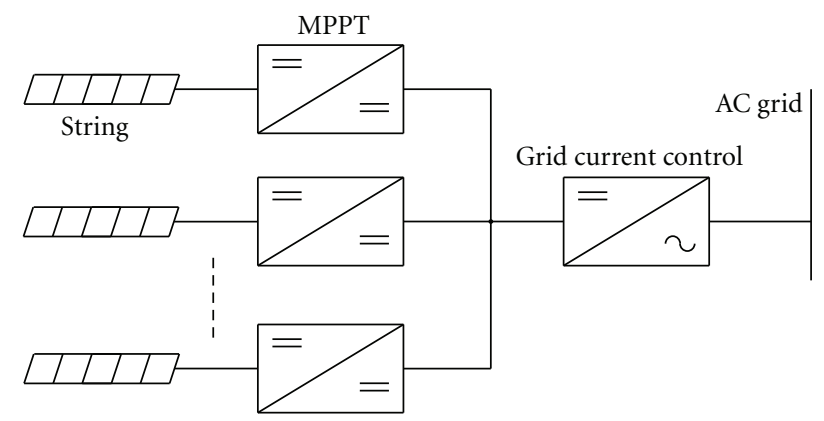

FIGURE 3: Low power DC-DC converters connected to strings and one large DC-AC in the grid interface.

a single dc-bus. A single or a dual-stage inverter can be employed. Figure 4 illustrates this configuration.

(ii) Multiple-string DC-DC converter: each string has a DC-DC converter, which can be galvanically isolated. There is a common DC link, which feeds a transformerless DC-AC converter. As shown in Figure 5 , only the multistage inverter can implement this configuration.

(iii) Multiple-string inverter: several PV modules are connected in series on the DC side to form a string. The output from each string is converted to AC through a smaller individual inverter. Many such inverters are connected in parallel on the AC side, as shown in Figure 6. A single or a dual-stage inverter can be employed in this kind of configuration.

(iv) Module-integrated inverter: each module has a small inverter, and each one is connected in parallel forming an ac-bus, which is connected to the AC grid. Once more, a single or a dual-stage inverter can be used. Figure 7 shows this configuration.

Table 1 summarizes the implementation options of a gridconnected PV power system.

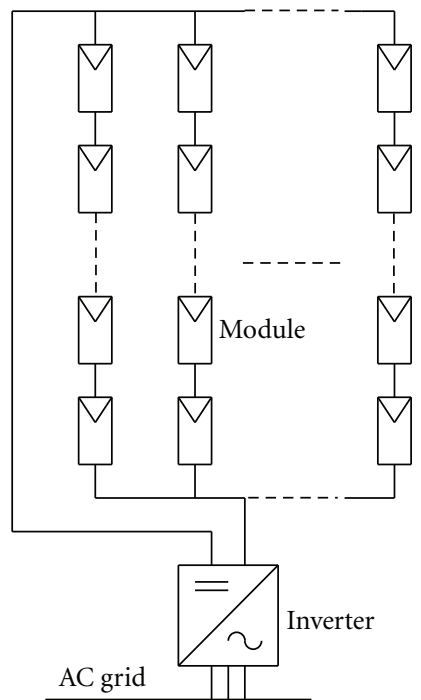

FIGURE 4: Central-plant inverter.

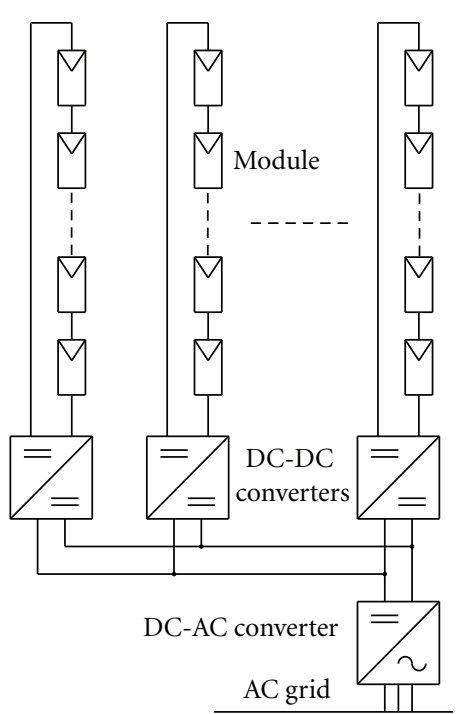

Figure 5: Multiple-string DC-DC converter.

The high efficiency is one of the most important characteristics of a PV inverter. Thus, whenever possible, these inverters are nonisolated electronic circuits, since a transformer imposes an efficiency drop. This efficiency drop is $2 \%$ larger for a low than that for a high-frequency transformer [1]. Hence, when grid isolation is mandatory, the 
TABLE 1: Implementation options of a grid-connected PV power system.

\begin{tabular}{lccc}
\hline Configurations & & Topologies & \\
& Single-stage inverter & Dual-stage inverter & Multistage inverter \\
\hline Central-plant inverter & $\checkmark$ & $\checkmark$ & $\boldsymbol{x}$ \\
Multiple-string DC-DC converter & $\boldsymbol{x}$ & $\checkmark$ & $\boldsymbol{x}$ \\
Multiple-string inverter & $\checkmark$ & $\checkmark$ & $\mathbf{x}$ \\
Module integrated inverter & $\checkmark$ & $\checkmark$ & \\
\hline
\end{tabular}

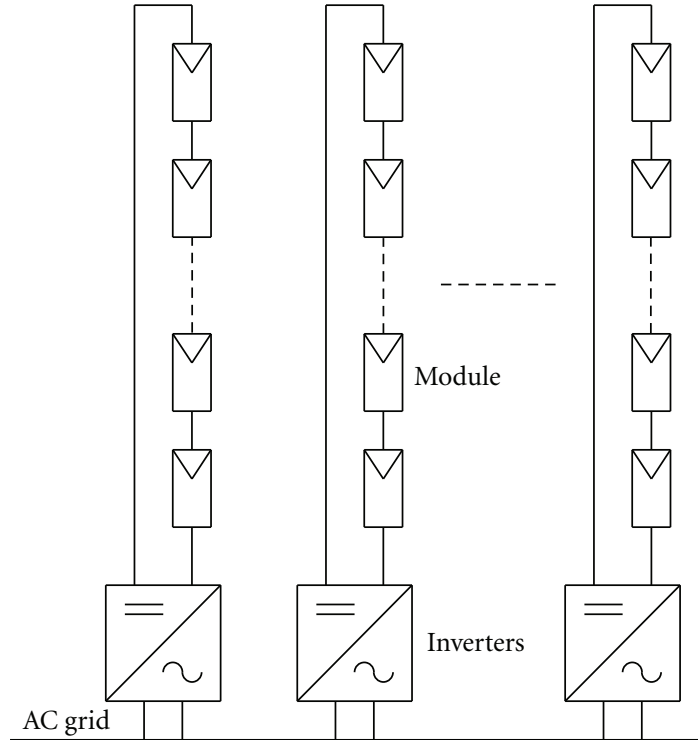

FIGURE 6: Multiple-string inverter.

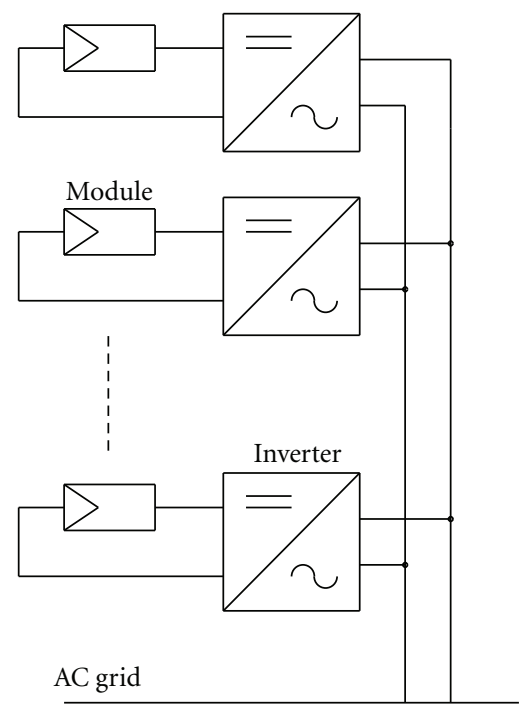

FIgURE 7: Module-integrated inverter.

incorporation of a high-frequency transformer is a trend. This implies the need for a DC-DC converter in the structure of the PV power system. The isolated ZVS Full-Bridge DCDC converter [31-38] is usually used at power levels above $750 \mathrm{~W}$ [24], to performer both the MPPT and the galvanic isolation. Commonly, its efficiency ranges from $92 \%$ to $93 \%$ under a $45 \%$ to $100 \%$ load condition [39]. This performance is not recommended for high power industrial applications. With nonisolated versions, the efficiency can be increased from $96 \%$ to $98 \%$ [39].

As an alternative to Full-Bridge based converters, the three-phase conversion has some advantages, such as the following [40].

(i) Reduced switching stresses of the power semiconductor devices.

(ii) Reduced size and ratings of associated reactive components.

(iii) Better transformer copper and core utilization.

As important as high efficiency, it is the inverter cost. The study in [24] indicates the centralization of inverter (centralplant inverter) for reducing cost, according to plant shown in Figure 4.

From the context previously presented, and considering to improve the volume and weight of the whole system, a dual-stage inverter configured in a central-plant, according to Figures 2 and 4, is proposed in this paper, however, with two basic differences.

(1) Uses a three-phase DC-DC converter in place of a single-phase. In [40], it is demonstrated that the three-phase conversion has some advantages such as the following.

(i) High-frequency transformer reduction in comparison to the transformer used in a Full-Bridge DCDC converter, operating with the same switching frequency.

(ii) Increase of three times in the input and output current frequencies, reducing the size of the filters components.

(iii) Better distribution of the losses.

The three-phase isolated DC-DC series resonant converter (SRC3) [41, 42] was applied to act as DC-DC stage. Despite the galvanic isolation, the measured efficiency of the DC-DC stage was limited to $96 \%-97.5 \%$ under a $45 \%-100 \%$ load condition.

(2) The MPPT will not be carried out by a DC-DC stage; it will be performed by the inverter, which is also responsible for the grid-current control. It is important to emphasize that any measurements of voltage or current in the photovoltaic array are made. It is an indirect MPPT, possibly due to the behavior matching between the DC-DC converter output I$V$ characteristic and the PV array $I-V$ characteristic, when 


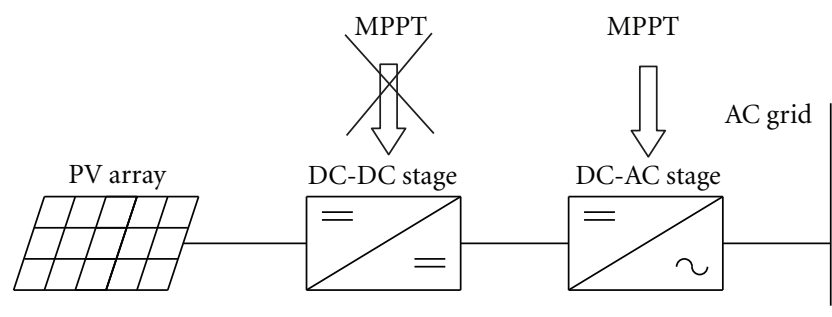

FIGURE 8: Modified dual-stage inverter.

they are connected. Then, behavior matching serves as a fundamental feature for DC-DC converters to reproduce the PV array $I-V$ characteristic without control action. The studies in [43-45] indicate this possibility.

The traditional dual-stage inverter implements some control strategy in the DC-DC stage [46-50]. In this paper, a conceptual modification is proposed that is called Modified Dual-Stage Inverter [51, 52]. In this new approach, there is no control in the DC-DC stage, the SRC3 operates with constant frequency and duty-cycle, representing a very high efficiency operation. All the control, MPPT, and grid-current are implemented in the DC-AC stage (inverter) that consists of a three-phase bidirectional power flow PWM voltage source inverter (VSI3). This is the principal power electronics circuit of a Three-Phase Grid-Connected PV Power System. Figure 8 shows the basic idea of a modified dual-stage inverter.

The DC-AC stage performs the MPPT through the P and O method $[22,49,53-58]$ to maximize the direct axis current, $I_{d}$, required for the grid current control. The current $I_{d}$ reflects the active power delivered by the photovoltaic array and is expressed through the inverter modeling, using the Park transformation $[59,60]$. Then, the inverter output power is maximized without additional sensors. In a single-stage inverter, this principle can also be used. Figure 9 presents the proposal topology for the dual-stage inverter in a three-phase configuration.

\section{Photovoltaic Array Modelling}

It was commented previously that the proposed MPPT is based on the behavior of the photovoltaic array by means of temperature and irradiation variations. Thus, the mathematical model of the PV cells is implemented in the form of a current source controlled by voltage, sensible to two input parameters, that is, temperature $\left({ }^{\circ} \mathrm{C}\right)$ and solar irradiation power $\left(\mathrm{W} / \mathrm{m}^{2}\right)$.

An equivalent simplified electric circuit of a photovoltaic cell is presented in Figure 10.

Although it is a simplified version, this equivalent circuit is enough to represent different types of photovoltaic cells when the temperature effects are considered [61]. From [62], it is verified that the cells of polycrystalline material are contemplated. This material is distinguished because information gotten of datasheet of a polycrystalline module is used in the simulation studies; however, the relevant aspects for the control, shown from the modeling, are not only applied to this type of material.
In a more complete version, the equivalent circuit of Figure 10 has two electrical resistors, $R_{s}$ and $R_{p}$ [63-65]. According to $[66,67]$, both resistors can be neglected. However, it is demonstrated that the series resistor, $R_{s}$, has a great impact on the inclination of the $I-V$ characteristic curve, becoming it more accurate between the maximum power operating point and the open circuit voltage. This information can also be found in [68].

Expression (1) can be obtained from Figure 10:

$$
I=I_{\mathrm{ph}}-I_{r} \cdot\left[e^{q \cdot\left(V+I \cdot R_{s}\right) / n_{p n} \cdot k \cdot T}-1\right],
$$

where $V$ and $I$ : voltage and current across the cell; $I_{\mathrm{ph}}$ : photocurrent; $I_{r}$ : cell reverse saturation current; $q$ : charge of an electron; $R_{s}$ : intrinsic series resistance of the cell; $n_{\mathrm{pn}}$ : ideality factor of the $p-n$ junction; $k$ : Boltzmann's constant; $T$ : temperature.

The photocurrent depends on the solar irradiation and the temperature, given by (2):

$$
I_{\mathrm{ph}}=\left[I_{\mathrm{sc}}+\alpha \cdot\left(T-T_{r}\right)\right] \cdot \frac{P_{\mathrm{sun}}}{1000},
$$

where $I_{\mathrm{sc}}$ : short-circuit current; $\alpha$ : temperature coefficient of the short-circuit current; $T_{r}$ : reference temperature, for standard condition; $P_{\text {sun }}$ : irradiance level. The standard power is $1000 \mathrm{~W} / \mathrm{m}^{2}$.

The reverse saturation current varies according to the temperature, as shown in (3):

$$
I_{r}=I_{r r} \cdot\left(\frac{T}{T_{r}}\right)^{3} \cdot e^{\left[\left(\left(q \cdot E_{G}\right) /\left(n_{p n} \cdot k\right)\right) \cdot\left(1 / T_{r}-1 / T\right)\right]},
$$

where $I_{r r}$ : cell reference reverse saturation current; $E_{G}$ : bandgap energy of the semiconductor used in the cell.

These equations can be found in $[66,69]$. The solution of (1) takes the characteristic curve for only one photovoltaic cell. However, the model is such that, if connected in a PV array form, it can be treated as only one cell with multiple associations in series and parallel [68]. Thus, the photovoltaic array, corresponding to two parallel-connected strings, is simulated. Each string contains ten modules, which approximately produce the operation voltage of $263 \mathrm{~V}$. Therefore, it is found that a $4 \mathrm{kWp}$ array formed by KC200GT modules from Kyocera. Figures 11 and 12 reflect the behavior obtained with the PV array modeling which is connected to DC-DC converter.

\section{Dual-Stage Inverter}

It is desired the system to be suitable for high power applications, above $10 \mathrm{~kW}$. Thus, the two stages of the inverter are three-phase configurations.

3.1. DC-DC Stage. When the single-phase DC-DC converter is replaced by a three-phase one, several advantages appear [40]:

(i) faster response times;

(ii) low stresses on active devices; 


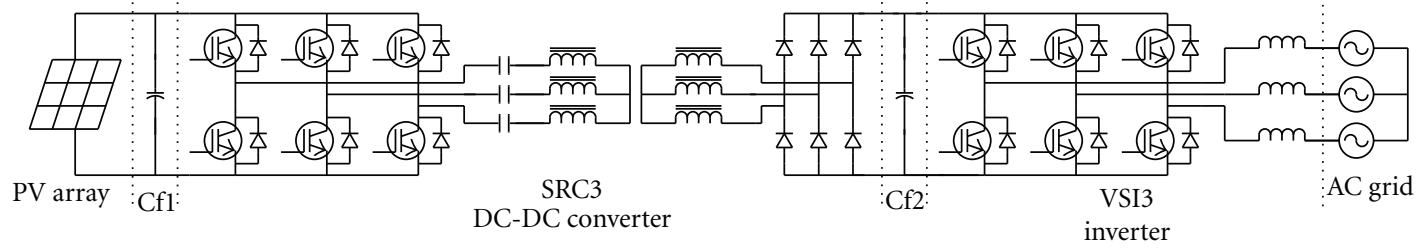

FIGURE 9: Three-phase dual-stage inverter in centralized configuration.

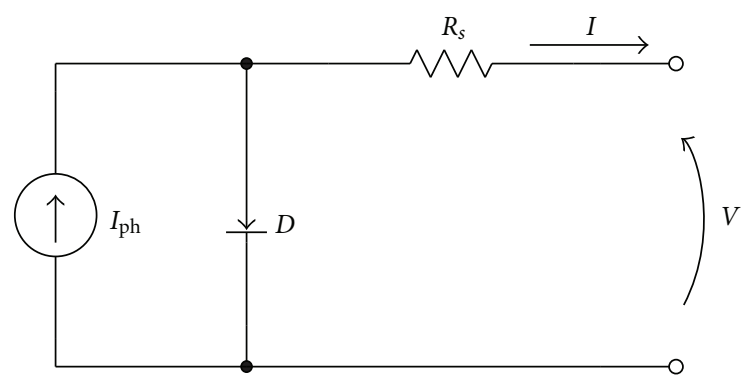

FIGURE 10: Equivalent electric circuit of a simplified single-diode model (SSDM) of a PV solar cell.

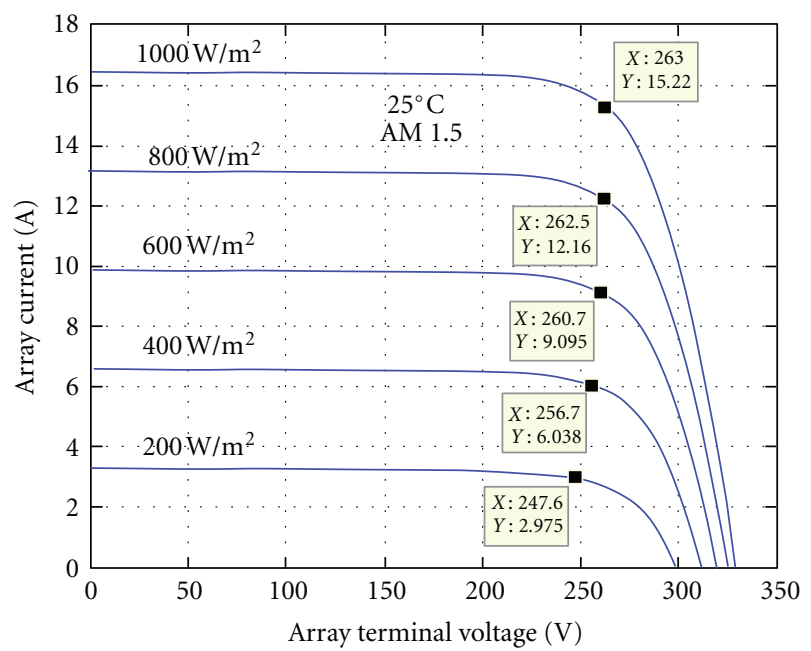

FIGURE 11: Current-voltage characteristics of photovoltaic array at various irradiance levels.

(iii) filters components reduction;

(iv) high-frequency transformer reduction.

Amongst the three-phase DC-DC converters, most attractive they are those that present soft commutation. This characteristic is important due to be high switching frequency in which they can operate, keeping the high efficiency and the heat sinks size in reasonable levels. In addition, with the rise of the switching frequency, a significant reduction in the transformer size and weight is obtained.

Various three-phase DC-DC converters with soft commutation are available [41, 42, 70-72]. Each of them was evaluated about the efficiency in different input power levels, components number, EMI emission, performance under

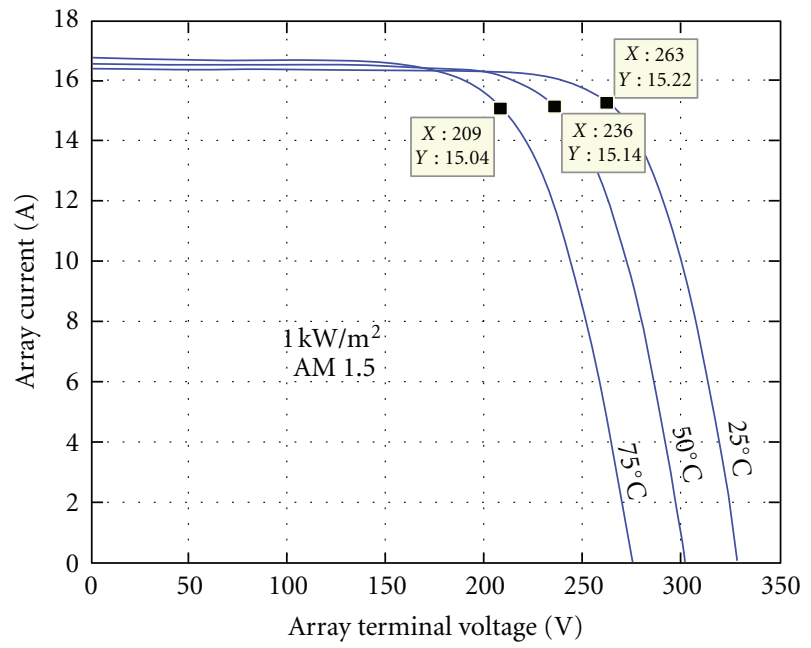

Figure 12: Current-voltage characteristics of photovoltaic array at various temperatures.

unbalanced conditions, and power range. The topology that appears to relate the best characteristics for the proposal application in this paper is presented in Figure 13, obtained from [42]. The transformer was replaced by their leakage inductances, Ld.

The switches are gated by 6 phase-shifted signals. Neglecting the deadtime between two switches in each inverter leg, all switches are turned on exactly half a period.

When the switching frequency, $f_{s}$, is equal to resonance frequency, $f_{r}$, the converter operates in ZCS. If $f_{s}>f_{r}$, the converter operates in ZVS. In this condition, the efficiency is much reduced for low-power transfer $[42,73]$. Then

$$
\begin{gathered}
f_{s}=f_{r}=\frac{1}{2 \cdot \pi \cdot \sqrt{\mathrm{Ld} \cdot C_{r}}}, \\
I_{\text {in }}=I_{\mathrm{pv}}=\frac{6}{\pi^{2} \cdot R_{\text {loss }}}\left(V_{\mathrm{in}}-V_{\mathrm{dc}}^{\prime}\right),
\end{gathered}
$$

where $I_{\mathrm{in}}$ : average input current; $I_{\mathrm{pv}}$ : PV array current; $V_{\mathrm{dc}}^{\prime}$ : average output voltage of the three-phase bridge rectifier, referred to the primary side; $V_{\text {in }}$ : average DC-DC converter input voltage; $R_{\text {loss }}$ : take all losses into account, such as the conduction and switching losses of the switches and diodes, the dielectric losses of the capacitors, the copper and iron losses of the three-phase transformer, and the conduction 


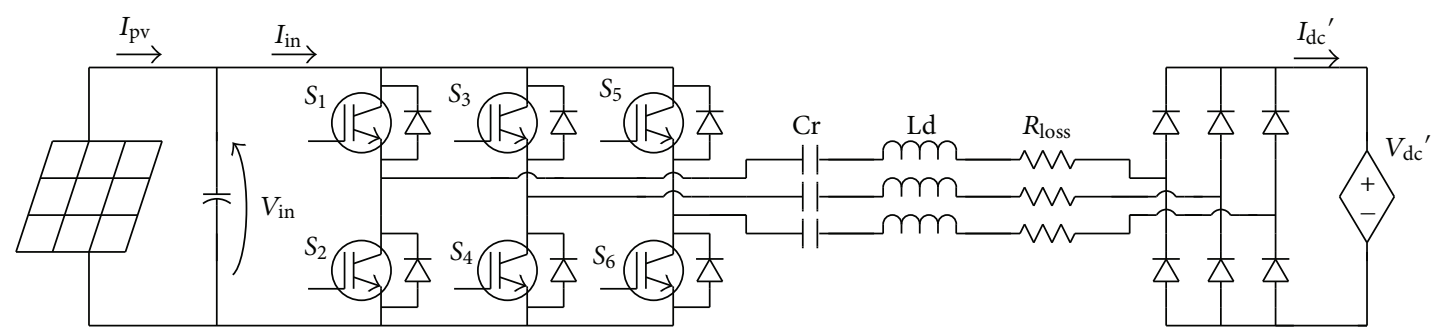

FIGURE 13: DC-DC three-phase series resonant converter (SRC3).

losses of wires and connections; Ld: leakage inductance of the transformer; $C_{r}$ : resonant capacitor.

The transformer turn's ratio can be defined by the following:

$$
n=\frac{N_{2}}{N_{1}}
$$

where $N_{1}$ : number of turns on the transformer primary winding; $N_{2}$ : number of turns on the transformer secondary winding.

From (5) and (6), (7) and (8) can be found:

$$
\begin{aligned}
R_{\mathrm{loss}} & =\frac{6}{\pi^{2} \cdot I_{\mathrm{in}}}\left(V_{\mathrm{in}}-\frac{V_{\mathrm{dc}}}{n}\right), \\
V_{\mathrm{in}} & =\frac{\pi^{2}}{6} \cdot R_{\text {loss }} \cdot I_{\mathrm{in}}+\frac{V_{\mathrm{dc}}}{n} .
\end{aligned}
$$

A peculiarity about this converter is that, despite the many advantages that it presents, it is inadequate for the accomplishment of MPPT, due to that its efficiency extremely depends on the implemented deadtime and switching frequency [42]. These variables should not vary. That deficiency can be neglected thanks to the Behavior Matching $[44,45,51$, $52,74]$.

3.2. DC-AC Stage. Two new trends for this stage are discussed in $[75,76]$, using LCL filters on a grid interface and replacing the conventional three-level PWM inverter by a multilevel inverter. The objectives are the same: lower total harmonic distortion (THD) and more compact designs. However, for the application presented in this paper, the three-phase current-controlled voltage-source inverter with $L$ filter is adequate.

The inverters used for grid interfacing are broadly classified as voltage-source inverters (VSI) and current-source inverters (CSI). The control schemes can be classified as current-controlled inverters (CCI) and voltage-controlled inverters (VCI).

PV solar arrays are fairly good approximation to a current source. Then, most PV inverters are voltage source. In addition, with vector modulation [77-82], the THD measured is insignificant when harmonics below the switching frequency are considered.

The current-controlled scheme objective is to control active and reactive components of the current fed into the grid. The current controllers are better suited for the control of power export from PV inverters to the utility grid since they are less sensitive to errors in synchronizing sinusoidal voltage waveforms [83]. The structure of the three-phase current-controlled voltage-source inverter is shown in Figure 14.

Performing a Park transformation, its dynamical model in the dq-frame can be described by the following:

$$
\begin{aligned}
\frac{d I_{d}}{d t} & =\frac{V_{d}}{L}+\omega \cdot I_{q}-\frac{R}{L} \cdot I_{d}-\frac{V_{\mathrm{dc}}}{L} \cdot D_{d}, \\
\frac{d I_{q}}{d t} & =-\omega \cdot I_{d}-\frac{R}{L} \cdot I_{q}-\frac{V_{\mathrm{dc}}}{L} \cdot D_{q}, \\
\frac{d V_{\mathrm{dc}}}{d t} & =-\frac{I_{\mathrm{dc}}}{\mathrm{Cf} 2}+\frac{I_{d}}{\mathrm{Cf} 2} \cdot D_{d}+\frac{I_{q}}{\mathrm{Cf} 2} \cdot D_{q},
\end{aligned}
$$

where $I_{d}, I_{q}, V_{\mathrm{dc}}$ : state variable; $D_{d}, D_{q}$ : control variables; $L=L_{1}=L_{2}=L_{3} ; R=R_{1}=R_{2}=R_{3}$ : intrinsic resistance of the inductance $L_{1}, L_{2}, L_{3}$, respectively; $V_{d}$, $\omega$ : utility grid parameters $\left(V_{d}=\sqrt{3} \cdot V_{g}\right.$, and $V_{g}$ is the grid rms phase voltage, and $\omega=2 \pi f$, where $f$ is the grid frequency); $I_{\mathrm{dc}}$ : average output current of the three-phase bridge rectifier, that is, the average input current of the three-phase VSI.

Since $P_{g}=V_{d} \times I_{d}$ represents the power that the inverter injects in the grid, the MPPT can be performed perturbing $V_{\mathrm{dc}}$ and observing $I_{d}$, according to the following:

$$
\begin{aligned}
V_{\mathrm{dc}}(k+1)= & V_{\mathrm{dc}}(k)+\Delta V \cdot \operatorname{sign}\left[V_{\mathrm{dc}}(k)-V_{\mathrm{dc}}(k-1)\right] \\
& \cdot \operatorname{sign}\left[I_{d}(k)-I_{d}(k-1)\right] .
\end{aligned}
$$

Setting $V_{\mathrm{dc}}$, the DC-AC stage defines the DC-DC converter's input characteristic behavior, who determines the PV array operation point. When $I_{d}$ is maximized, the PV array operates on MPOP. As noted, $I_{d}$ and $V_{\mathrm{dc}}$, used by MPPT, are state variables employed in the grid-current control, that is, additional hardware is not need. Section 4 explains this behavior in detail, which represents the behavior matching of the proposed dual-stage inverter.

\section{Behavior Matching and the MPPT Proposal Technique}

The indirect MPPT is a type of tracking that uses the connection between measured variables and the position of the maximum power operating point (MPOP). Some 


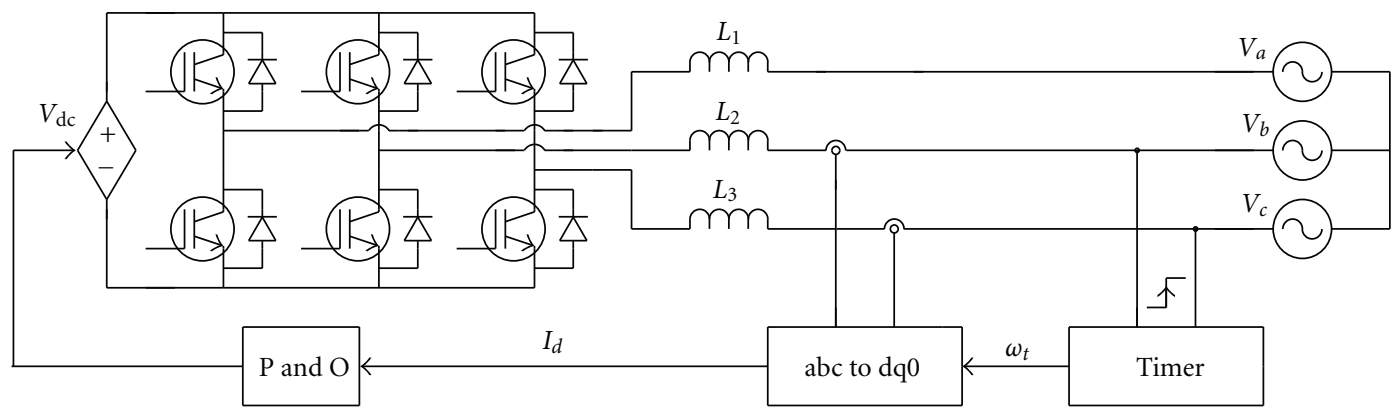

FIGURE 14: Three-phase current-controlled VSI.

variables as temperature and PV generator's open circuit voltage are used. It is not a true MPPT technique.

The direct MPPT requires, in principle, a measurement of generator voltage and current as well as a multiplication of these variables [84-95].

In both cases, specific measurements for MPPT are made. In the proposed grid-connected dual-stage inverter, the direct axis current, $I_{d}$, is observed, which serves for the inverter stage to set $V_{\mathrm{dc}}$. These actions define the DC-DC converter's input characteristic behavior, which determines the PV array operation point [96]. When $I_{d}$ is maximized, the PV array operates on MPOP. As noted, the variables used in the MPPT are $I_{d}$ and $V_{\mathrm{dc}}$, initially employed in the grid current control, that is, any specific measurement for MPPT's purpose is made.

The DC-DC converter operates with constant duty cycle and frequency. It is designed to work with an efficiency of $97 \%$ coupled to the PV array shown in Section 3.1, working under Standard Test Conditions (STC) (irradiance of $1 \mathrm{~kW} / \mathrm{m}^{2}$, spectrum of 1.5 air mass, and cell temperature of $25^{\circ} \mathrm{C}$ ), resulting in $R_{\text {loss }}=0.32 \Omega$ and $V_{\mathrm{dc}}^{\prime}=255 \mathrm{~V}$. Thus, (5) results in

$$
I_{\text {in }}=1.9\left(V_{\text {in }}-255\right) \text {. }
$$

Equation (11) is drawn in Figure 15. This illustration also demonstrates that when MPPT is put in action by the inverter stage, $V_{\mathrm{dc}}$ vary, it shifts the DC-DC converter input $I-V$ characteristic.

The Behavior Matching depends on the DC-DC converter input characteristic at an operation point. Several single and three-phase converters exhibit appropriate input characteristic to present Behavior Matching [45, 50, 94, 97101]. In the case of SRC3, the input characteristic curve is a straight line with a small inclination.

It is important to register that this inclination favors the MPPT on irradiation variations. If this straight line fall together with the line formed by union of the MPOPs, would not be necessary the intervention of the inverter stage is necessary just in the temperature variations, when $V_{d}$ must be changed in order to move the straight line for a new position, searching the MPOP. Putting upon Figures 11 and 15 , the approaching between the DC-DC converter's input

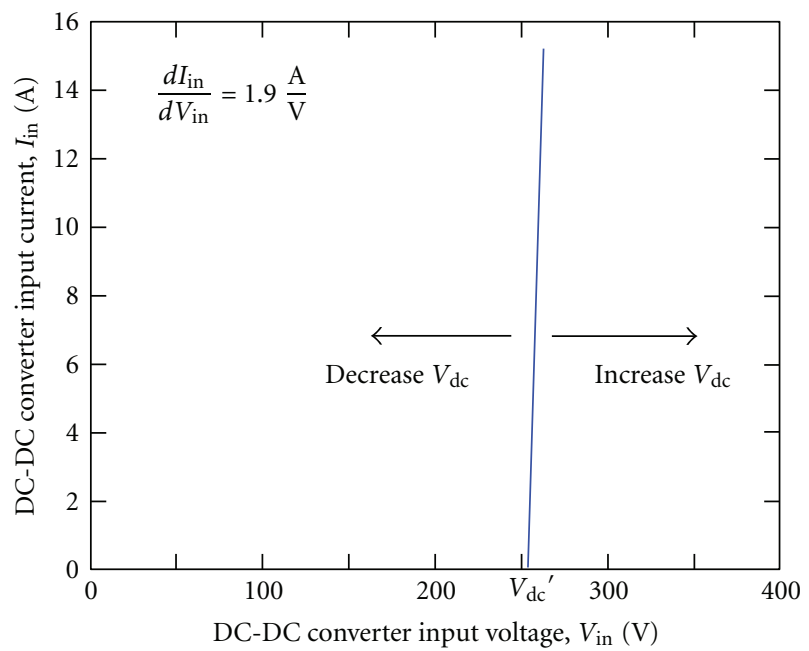

FIGURE 15: DC-DC converter input $I-V$ characteristic.

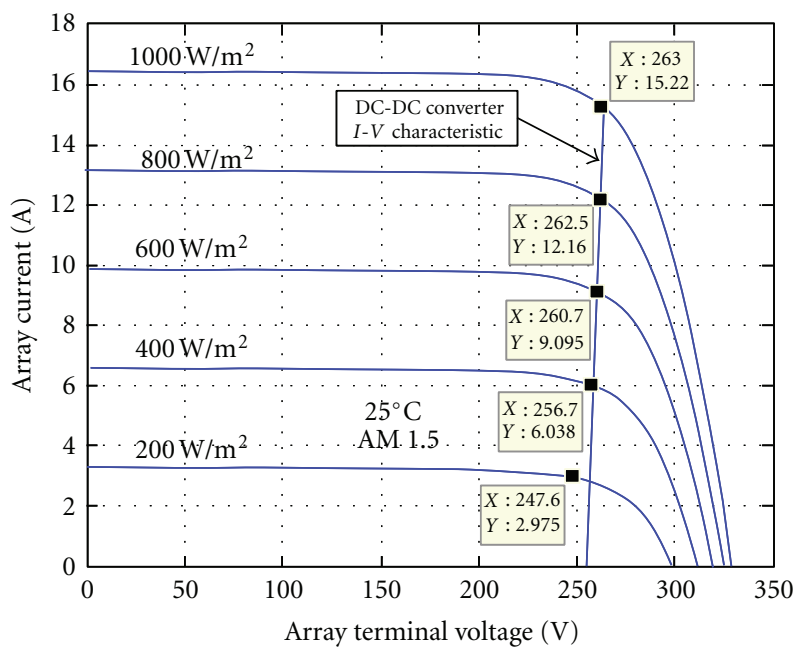

FIgURE 16: Crossing between SRC3 and $4 \mathrm{kWp}$ PV array $I-V$ characteristic curves.

characteristic and the MPOPs can be found, as shown in Figure 16.

The PV array operation point is defined by the crossing of its respective $I-V$ characteristic curve with the DC-DC 


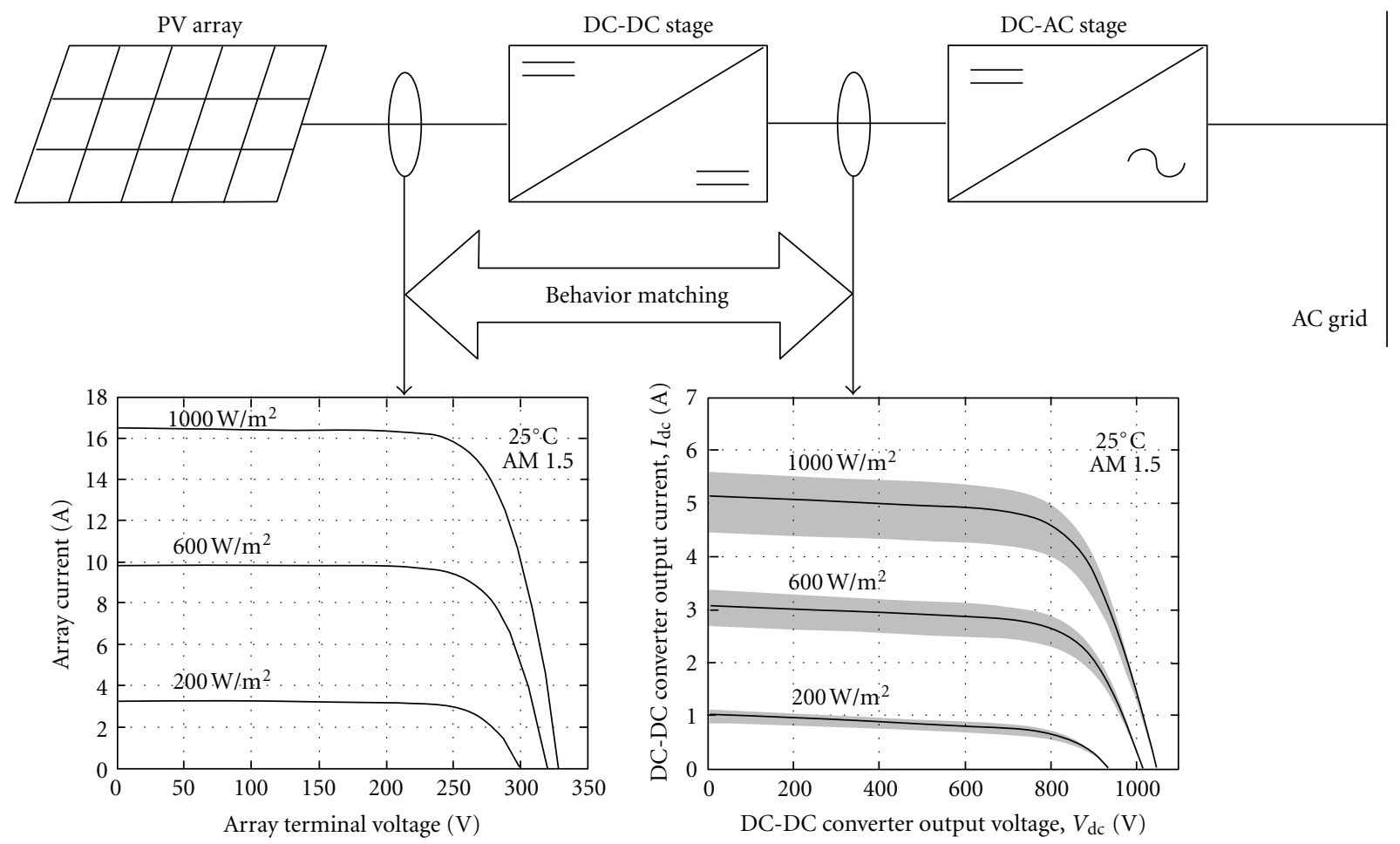

FIGURE 17: Behavior matching verifying.

converter input characteristic curve. Then, $I_{\mathrm{pv}}$ and $I_{\mathrm{dc}}$ are also defined. Figure 17 presents simulation results where it can be seen that the PV array behavior, represented by its I$V$ characteristic, is reproduced on the DC-DC stage output terminals, represented by $I_{\mathrm{dc}} \times V_{\mathrm{dc}}$. From the controller point of view, $I_{\mathrm{dc}} \times V_{\mathrm{dc}}$ is similar to $I_{\mathrm{pv}} \times V_{\mathrm{in}}$. Thus, MPPT task is to extract the maximum power of the DC link, or to inject the maximum power in the grid. The strategies are different, but the result is the same: both tune the DC-DC stage input $I-V$ characteristic to the PV array MPP. Therefore, Figure 17 shows that the DC-DC stage's output has behavior matching that of the PV array's output terminals.

The Behavior Matching Technique bring significant advantages always that the input characteristic curve of the DC-DC converter is located near the MPP of the PV array, for all tracking algorithm range. Step-down DC-DC converters, with similar input Buck behavior, are eligible to integrate a modified dual-stage inverter.

4.1. MPPT Proposed Technique Using $P$ and $O$ Algorithm. The $\mathrm{MPPT}$ proposed technique, using $\mathrm{P}$ and $\mathrm{O}$ algorithm, has the following procedure.

The temperature and the solar irradiation in the PV array modules vary in different ways. The clouds movement can result in brusque alterations in the irradiance level. However, the temperature tends to vary much more slowly.

The MPOP can be tracked by a DC-DC converter through its input characteristic. Since temperature remains constant, there is no necessity for the inverter intervention, whose task is to keep the voltage $V_{\mathrm{dc}}$ clamped in a reference.
However, periodically, the inverter, through a $\mathrm{P}$ and $\mathrm{O}$ algorithm, regulates the value of $V_{\mathrm{dc}}$ in order to shift the DC-DC converter input characteristic, which can be crossing with the array $I-V$ characteristic far from the MPOP due to a temperature variation. Besides $\mathrm{P}$ and $\mathrm{O}$, others algorithms can also be used.

The topology of the inverter is presented in Figure 14, where $V_{a}, V_{b}$, and $V_{c}$ represent the AC grid phase voltages. It is verified that $\mathrm{P}$ and $\mathrm{O}$ block is fed by the direct axes current, $I_{d}$, obtained from Park's transformation. According to [102], the power that the inverter injects in the grid is given by $P_{g}=V_{d} \times I_{d}$, where $V_{d}$ is constant. Thus, the MPPT can be indirectly performed, perturbing $V_{d}$ and observing $I_{d}$. The $V_{d}$ perturbation at the $(k+1)$ th sampling is given by $(10)$.

\section{Design Example}

The PV array consists of two parallel strings, each with ten KC200GT modules from Kyocera. This PV array defines the nominal input power of the dual-stage inverter, whose value is $P_{\text {in }}=4 \mathrm{~kW}$, with $V_{\text {in }}=263 \mathrm{~V}$ and $I_{\text {in }}=15.2 \mathrm{~A}$. The estimated efficiency for the DC-DC stage is $\eta_{\mathrm{DC}}=97 \%$. Then, the output power of the DC-DC stage is $P_{\mathrm{dc}}=3880 \mathrm{~W}$ and the same value in the input of the DC-AC stage is obtained. The switching frequencies of the DC-DC and DC-AC stages are $f_{\mathrm{DC}}=40 \mathrm{kHz}$ and $f_{\mathrm{AC}}=20 \mathrm{kHz}$, respectively. The grid rms phase voltage is $V_{g}=220 \mathrm{~V}$.

5.1. PV Array Parallel Capacitor (Cf1). The PV array parallel capacitor is obtained from (12), where $\Delta V_{\text {in }}$ is the 


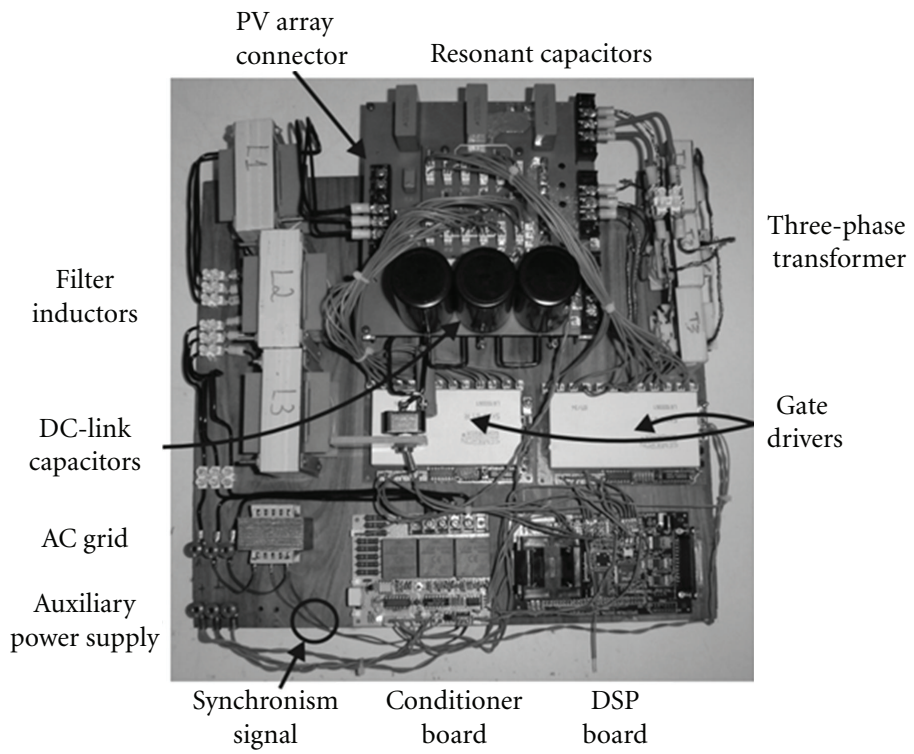

FIGURE 18: Laboratory prototype of the modified dual-stage inverter.

peak-to-peak ripple on the DC-DC stage input voltage. The adopted value is $\Delta V_{\text {in }}=1.0 \% V_{\text {in }}=2.63 \mathrm{~V}$ :

$$
\text { Cf } 1 \geq \frac{I_{\text {in }}}{215 \cdot f_{\mathrm{DC}} \cdot \Delta V_{\text {in }}}=\frac{15.2}{215 \cdot 40 \mathrm{k} \cdot 2.63} \geq 672.03 \mathrm{nF} .
$$

A polyester capacitor of $680 \mathrm{nF}$ is used.

5.2. DC-AC Stage Input Capacitor (Cf2). According to (13) [73], the input capacitor of the DC-AC stage is obtained. The ripple $\Delta V_{\mathrm{Cf} 2}$ needs to be a magnitude perturbation's percentage involved in the $\mathrm{P}$ and $\mathrm{O}$ algorithm. The adopted value is $\Delta V_{\mathrm{Cf} 2}=0.2 \mathrm{~V}$, while the magnitude perturbation is $4 \mathrm{~V}$ :

$$
\begin{aligned}
\mathrm{Cf} 2 & \geq \frac{P_{\mathrm{dc}}}{12 \cdot \sqrt{2} \cdot V_{g} \cdot \Delta V_{\mathrm{Cf} 2} \cdot f_{\mathrm{AC}}} \\
& =\frac{3880}{12 \sqrt{2} \cdot 220 \cdot 0.2 \cdot 20 \mathrm{k}} \geq 259.81 \mu \mathrm{F} .
\end{aligned}
$$

The adopted value of $\mathrm{Cf} 2$ is $333 \mu \mathrm{F}$, obtained by a series association of three electrolytic capacitors of $1000 \mu \mathrm{F}$.

5.3. Grid Line Inductors $\left(L=L_{1}=L_{2}=L_{3}\right)$. The grid line inductors are calculated by (15), assuming phase current ripple equal to $\Delta I_{L}=0.42 \mathrm{~A}$. This value corresponds to $5 \%$ of the peak line current, obtained by (14) and is sufficient to keep the THD below 5\% [73]:

$$
\begin{gathered}
I_{\mathrm{Lpk}}=\frac{\sqrt{2} \cdot P_{\mathrm{dc}}}{3 \cdot V_{g}}=\frac{\sqrt{2} \cdot 3880}{3 \cdot 220}=8.31 \mathrm{~A}, \\
L=\frac{\sqrt{2} \cdot V_{g}}{4 \cdot f_{\mathrm{AC}} \cdot \Delta I_{L}}=\frac{\sqrt{2} \cdot 220}{4 \cdot 20 \mathrm{k} \cdot 0.42} \Longrightarrow L=9.3 \mathrm{mH} .
\end{gathered}
$$

5.4. Resonant Capacitor ( $\mathrm{Cr}$ ). The three-phase transformer is constructed with three single-phase transformers, in wye connection. The turns ratio is defined by $n=N_{2} / N_{1}=$ 3.2. The leakage inductances have been measured to $\mathrm{Ld}=$ $3.6 \mu \mathrm{H}$. Applying (4), this results in a resonant capacitor of $\mathrm{Cr}=4.4 \mu \mathrm{F}$, for ZCS operation. Polypropylene capacitors were adopted.

5.5. Average DC-Link Voltage Referred to Primary Side $\left(V_{d c}^{\prime}\right)$. The average DC-link voltage referred to primary side can be calculated from (16) [73]:

$$
V_{\mathrm{dc}}^{\prime}=\eta_{\mathrm{DC}} \cdot V_{\mathrm{in}}=0.97 \cdot 263 \Longrightarrow V_{\mathrm{dc}}^{\prime}=255 \mathrm{~V} \text {. }
$$

The voltage presented in (16) is raised to $V_{\mathrm{dc}}=816 \mathrm{~V}$ by $n=3.2$. This turns ratio keeps the DC-link voltage above $600 \mathrm{~V}$ for all MPPT ranges.

5.6. Converter Losses Resistance $\left(R_{\text {loss }}\right)$. In nominal conditions, to sinusoidal resonant currents, the losses are found around $R_{\text {loss }}=0.32 \Omega$, according to (7).

5.7. Main Data of the Laboratory Prototype. A SK20GD065 Semikron IGBT module was used. The diode bridge was made with six ultrafast recovery rectifiers FFPF05U120S, of $1200 \mathrm{~V}$ and $5 \mathrm{~A}$. A top view of the prototype is depicted in Figure 18.

\section{Simulation and Experimental Results}

The specifications of the whole system are given in Section 5 .

6.1. DC-DC Three-Phase Series Resonant Converter (SRC3) Performance. A compare unit pertained to a peripheral of the Texas TMS320F2812 controller was configured to generate six gate pulses for SRC3, with duty cycle of $50 \%$ and deadtime 


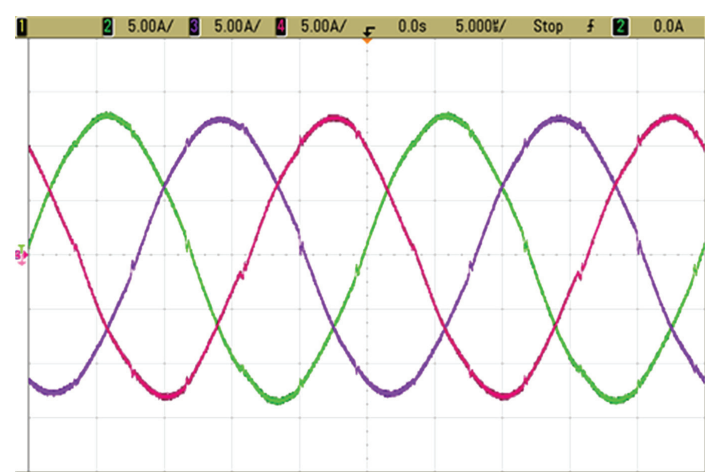

Figure 19: Resonant currents under nominal conditions.

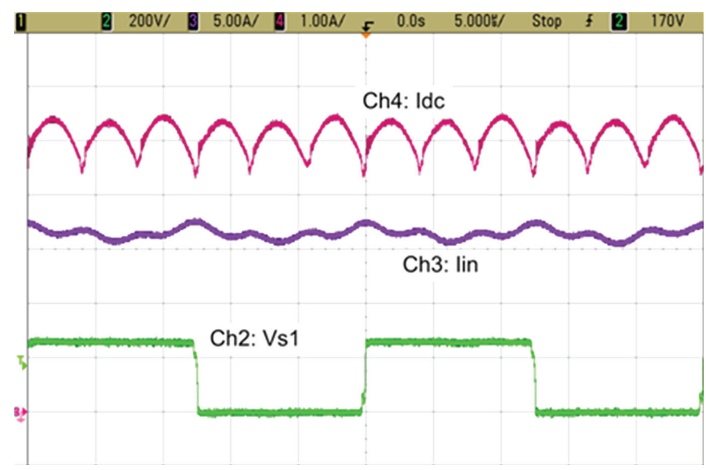

Figure 20: Input and output currents of the DC-DC stage and collector-emitter voltage, under nominal conditions.

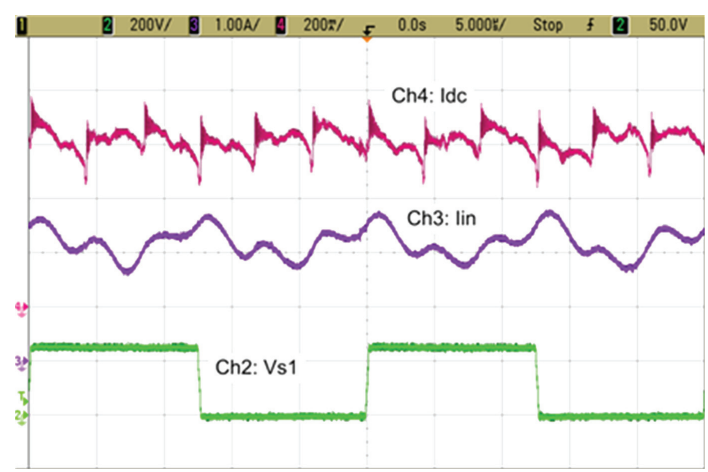

FIgURE 21: Input and output currents of the DC-DC stage and collector-emitter voltage, with $P_{\mathrm{dc}}=500 \mathrm{~W}$.

of $640 \mathrm{~ns}$. The same DSP carried out the grid-current control and the MPPT.

Figure 19 shows the resonant currents. Obviously, the leakage inductances of each phase are not exactly the same. These asymmetries cause small differences in resonant currents amplitudes. However, this has a negligible impact on the SRC3 operation.

Figures 20 and 21 present the input and output currents of the DC-DC stage for different power conditions. These currents have a low ripple and a frequency of six times that of the switching frequency, resulting in a continuous power flux. These features are not common among three-phase DC-DC converters and lead to reduced filter devices. The PV array

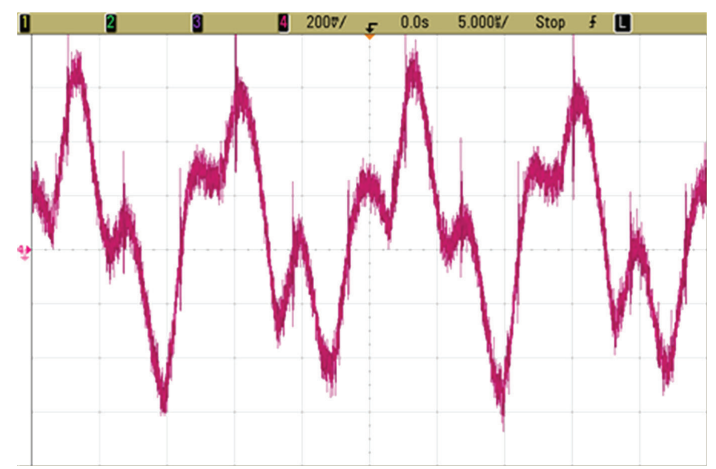

FIGURE 22: PV array output voltage for $P_{\mathrm{dc}}=500 \mathrm{~W}(400 \mathrm{mV} / \mathrm{div})$.

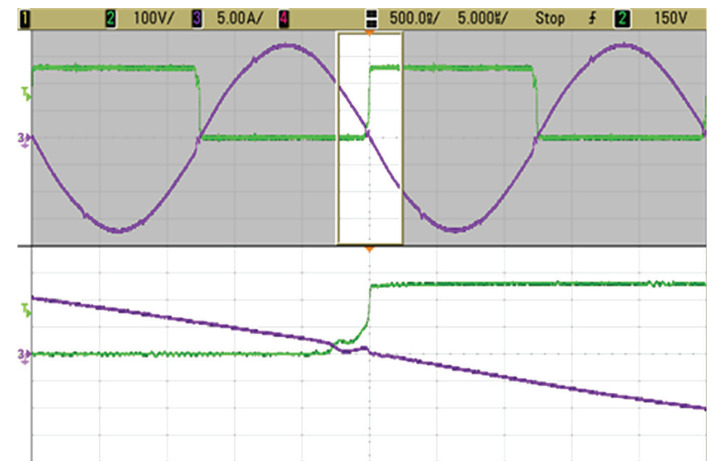

FIGURE 23: Resonant current and collector-emitter voltage, under nominal conditions.

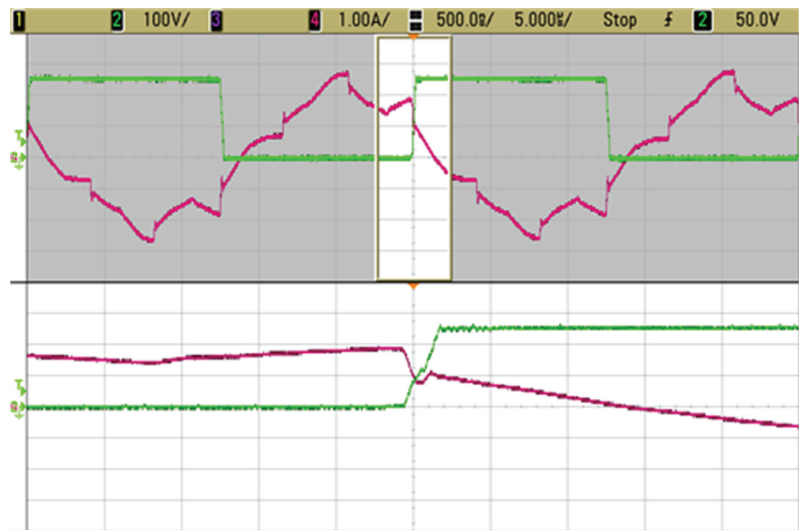

FIGURE 24: Resonant current and collector-emitter voltage, for $P_{\mathrm{dc}}=$ $500 \mathrm{~W}$.

parallel capacitor is of only $680 \mathrm{nF}$, for example. The voltage ripple on it is showed in Figure 22. This ripple was produced by the current $I_{\text {in }}$ of Figure 21. It has a negligible impact above $\mathrm{PV}$ array efficiency.

The ZCS commutation is shown in detail in Figure 23. Unfortunately, the commutation losses drastically increase at low power levels, according to Figure 24. Figure 25 shows the SRC3 efficiency.

6.2. Behavior Matching. This subsection presents experimental results that validate the Behavior Matching technique. 


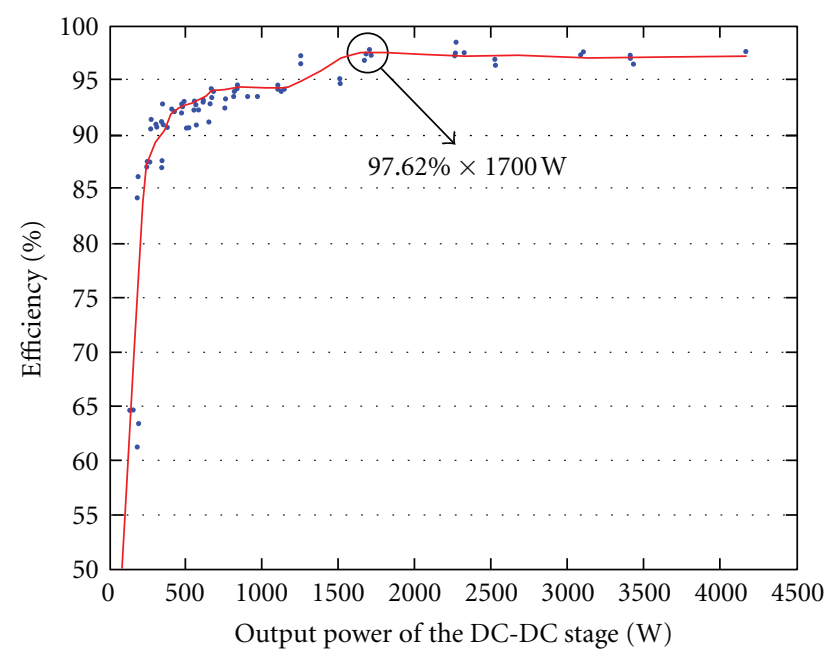

FIGURE 25: SRC3 efficiency.

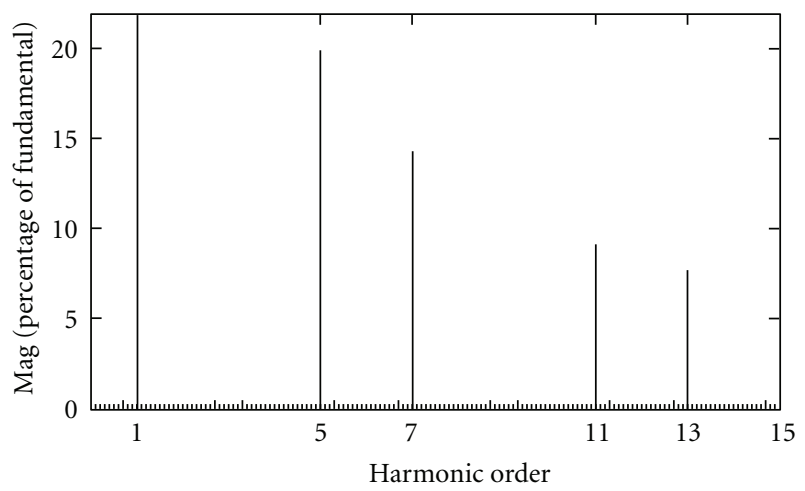

FIGURE 26: Harmonic spectrum of the voltage across the resonant circuit.

Figure 26 shows the harmonic spectrum of the voltage across the resonant circuit [42]. The fundamental frequency is $40 \mathrm{kHz}$, that is, the resonant frequency.

The impact of the voltage harmonic components on the resonant current depends on the resonant circuit quality factor, presented as follows:

$$
Q=2 \cdot \pi \cdot f_{r} \cdot \frac{\mathrm{Ld}}{R_{\text {loss }}} .
$$

The requirement of large impedance for frequencies that are different of the resonant frequency is fulfilled when the quality factor $Q$ is high. The value of $Q$ is high in nominal conditions, such as Figure 23. On the other hand, for low SRC3 output power rate, the $Q$ value is low too, according to Figure 24. This occurs due increasing of $R_{\text {loss }}$ for output powers below of approximately $1700 \mathrm{~W}$. Figure 25 points to decreasing of efficiency below this power. Larger Ld could reduce the power from which $R_{\text {loss }}$ rises. The efficiency would be more flat.

Figure 27 depicts the consequence of the resonant current distortion. For high rated power, the ratio $I_{\mathrm{in}} / I_{\mathrm{dc}}=3.2=n$. For low rated power, the ratio transformer is affected.

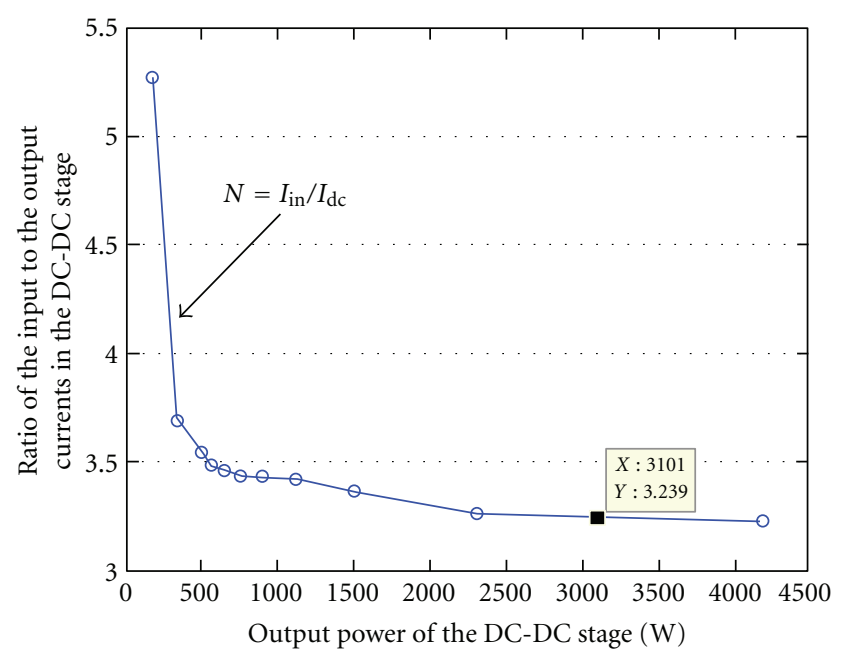

FIGURE 27: Input and output currents ratio in the DC-DC stage.

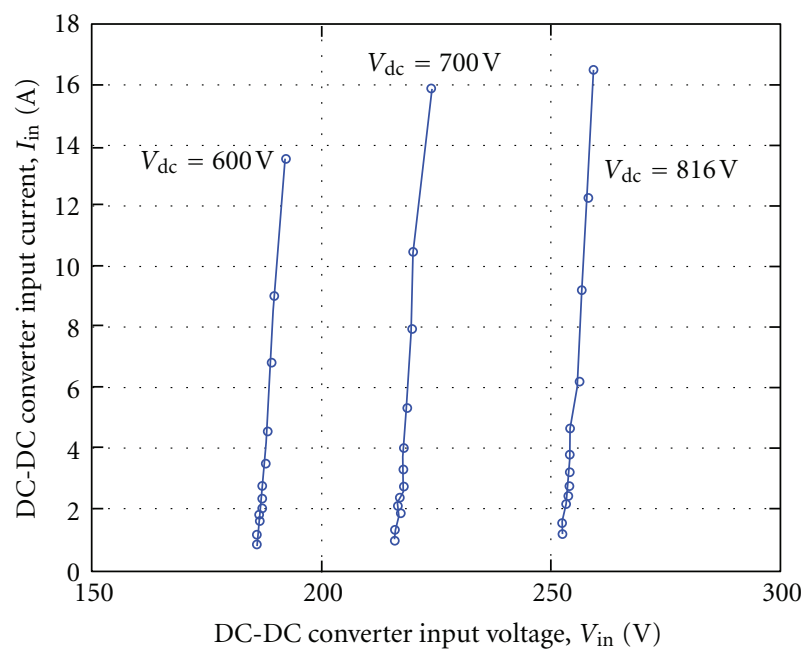

FIGURE 28: DC-DC converter input $I-V$ characteristics.

In conclusion, when $R_{\text {loss }}$ increases, the equivalent ratio transformer $\left(I_{\text {in }} / I_{\mathrm{dc}}\right)$ also rises.

Reporting to (8), it is verified that $V_{\text {in }}$ could be continuously reduced with the DC-DC stage output power reduction. This effect is depicted in Figure 28. Thus, variations in $R_{\text {loss }}$ are compensated by variations in the equivalent ratio transformer. Moreover, they have the same cause.

The inclination of the SRC3 input $I-V$ characteristic, for all $V_{\mathrm{dc}}$ operation range, is given by (18), obtained from (5). Figure 28 shows experimentally measured points of SRC3 prototype input $I-V$ characteristic

$$
\frac{d I_{n}}{d V_{\text {in }}}=\frac{6}{\pi^{2} \cdot R_{\text {loss }}}=2.3 \mathrm{~A} / \mathrm{V}
$$

The DC-DC converter's input characteristic has a propitious behavior to MPPT algorithm. Putting Figure $28\left(V_{\mathrm{dc}}=\right.$ $816 \mathrm{~V}$ ) on the PV array $I-V$ characteristic curves, the proximity between the DC-DC converter's input characteristic and the MPP loci can be established, as shown in Figure 29. This 


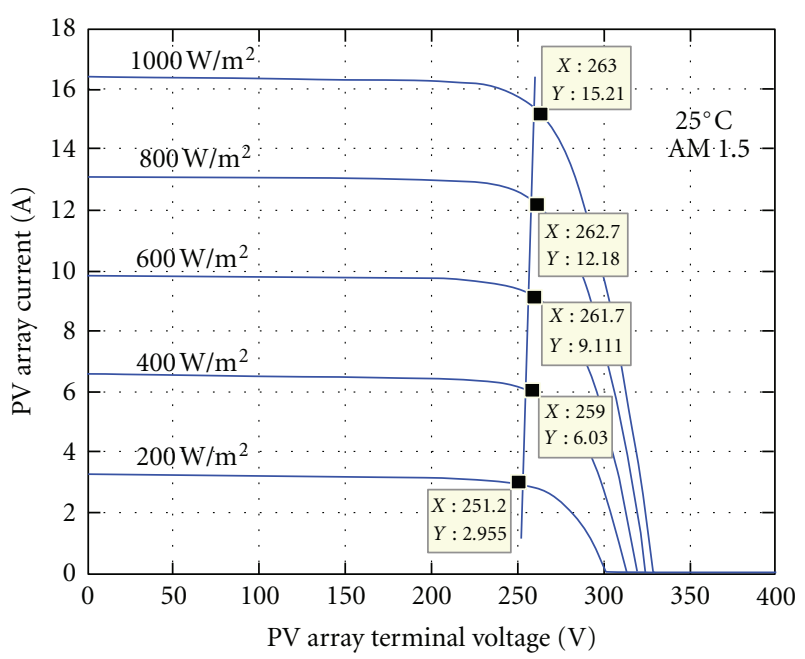

Figure 29: Crossing between SRC3 and PV array characteristic curves.

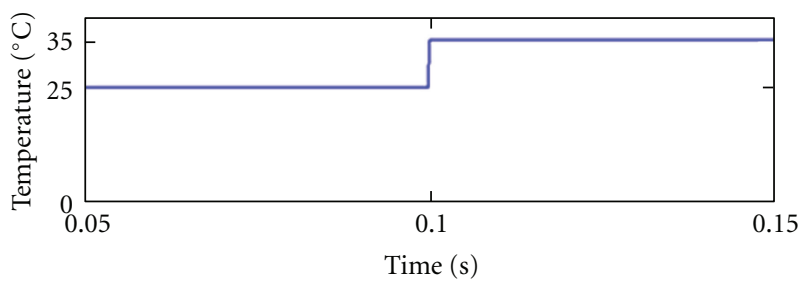

(a)

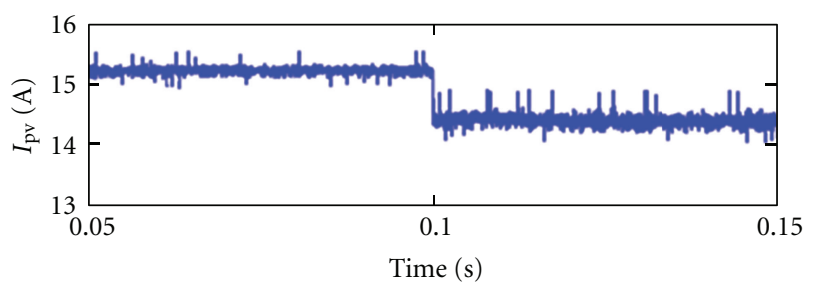

(b)

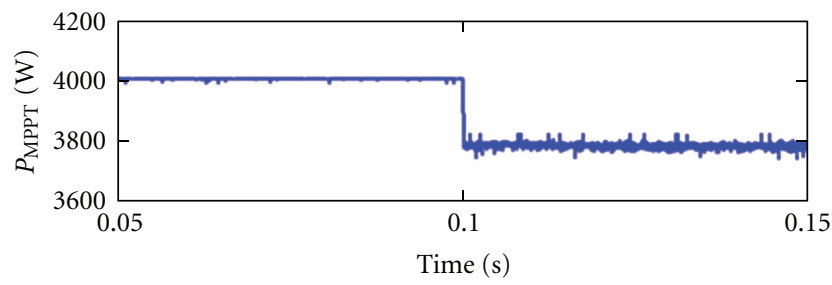

(c)

FIgURE 30: Temperature variation and consequences.

collaborates with the MPPT performance for fast changes in atmospheric conditions.

6.3. MPPT Performance. This subsection presents simulation results that reflect the possibility to perform the MPPT using the direct axis current $\left(I_{d}\right)$.

The mathematical model of a $4 \mathrm{kWp}$ PV array is accurately implemented in the form of a current source controlled by voltage, sensible to two input variables, that is, temperature

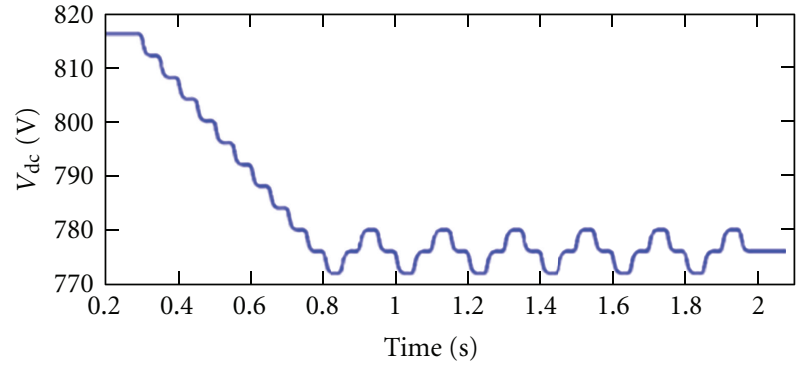

(a)

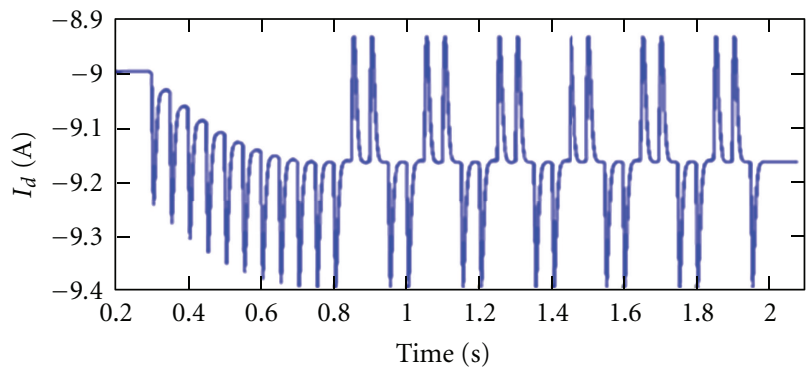

(b)

FIgURE 31: Execution of the $V_{\mathrm{dc}}$ perturbation and $I_{d}$ observation algorithm.

and solar irradiation power. This model simulates the physical PV array.

The MPOP's shift is an almost horizontal line when the temperature changes, see Figure 12. The intersection between the characteristics of the PV array and DC-DC converter can deviates from the MPOP. If $V_{\mathrm{dc}}$ is keeping constant, thus $V_{\text {in }}$ stays, approximately, constant too. This implies that $I_{\mathrm{pv}}$ and the power from PV array $\left(P_{\mathrm{MPPT}}\right)$ will decrease. Figure 30 shows the consequences of cell's temperature changes from $25^{\circ} \mathrm{C}$ to $35^{\circ} \mathrm{C}$. The irradiance is $1 \mathrm{~kW} / \mathrm{m}^{2}$ and the air mass is of 1.5 .

In order to solve this problem, the $\mathrm{P}$ and $\mathrm{O}$ method is put in action in the DC-AC stage, as shown in Figure 31. The $\mathrm{P}$ and $\mathrm{O}$ parameters are $T_{a}=50 \mathrm{~ms}$ and $\Delta V=4 \mathrm{~V}$ ( $\Delta V$ is the perturbation magnitude and $T_{a}$ is the sampling interval). Thus, in order to maximize the $I_{d}$ current, each $50 \mathrm{~ms}$, the $V_{\mathrm{dc}}$ voltage is perturbed by $4 \mathrm{~V}$ on its magnitude. This perturbation can be added or subtracted of $V_{\mathrm{dc}}$. The MPPT algorithm resolves based on the variation of $I_{d}$. The system uses a turns ratio transformer of $1: 3.2$. Figure 32 shows a zoom on the PV array characteristic curves with the positions (initial, intermediate, and final) of the operation point.

Figure 33 depicts the trajectory of the PV array output power $\left(P_{\mathrm{MPPT}}\right)$ as a consequence of the $V_{\mathrm{dc}}$ adjustments, drawn from Figure 31. The relative tracking error, $\varepsilon_{R}$, practically achieves zero in steady state conditions. This occurs due to the shifting of the SRC3 input $I-V$ characteristic close to the MPOP.

6.4. Performance of the DC-AC Three-Phase Stage. The DCAC stage is performed by a three-phase PWM voltage source 


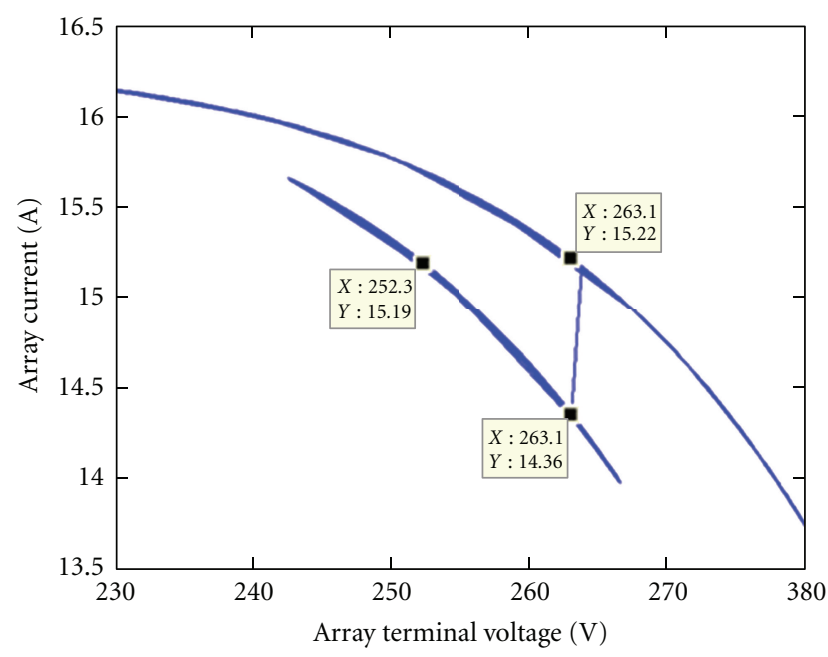

FIgURE 32: $I-V$ characteristic curves of the PV array.

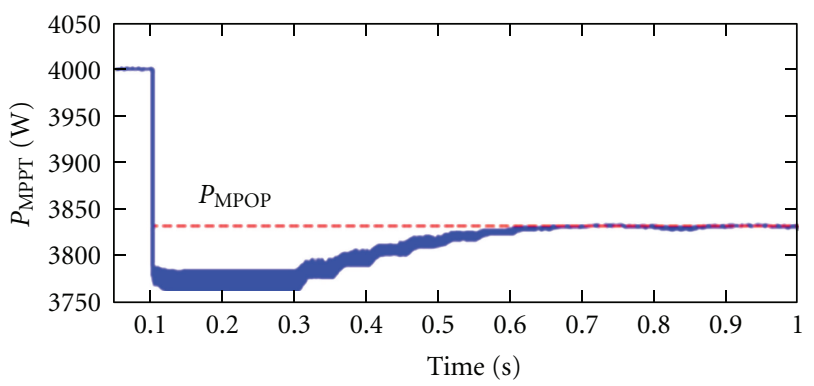

(a)

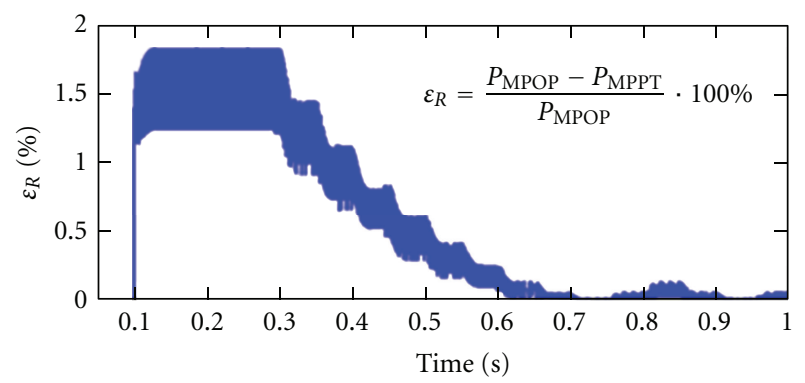

$P_{\mathrm{MPOP}}$ : maximum power that the PV array can supply, in the respective conditions of temperature and irradiation;

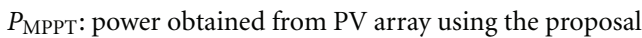
MPPT method

(b)

FIGURE 33: MPPT performance.

inverter (VSI3) controlled by current, whom power topology is presented in Figure 14. The space vector modulation (SVM) is used in order to minimize the THD of the grid current.

Figure 34 depicts the utility voltage and the current transferred to the main power supply, both in phase a, for rated power condition. The THD of the voltage and current is shown in Figures 35 and 36, respectively. An efficiency of 95\% was obtained for the DC-AC stage, and $92 \%$ for the whole system, including the DC-DC stage.

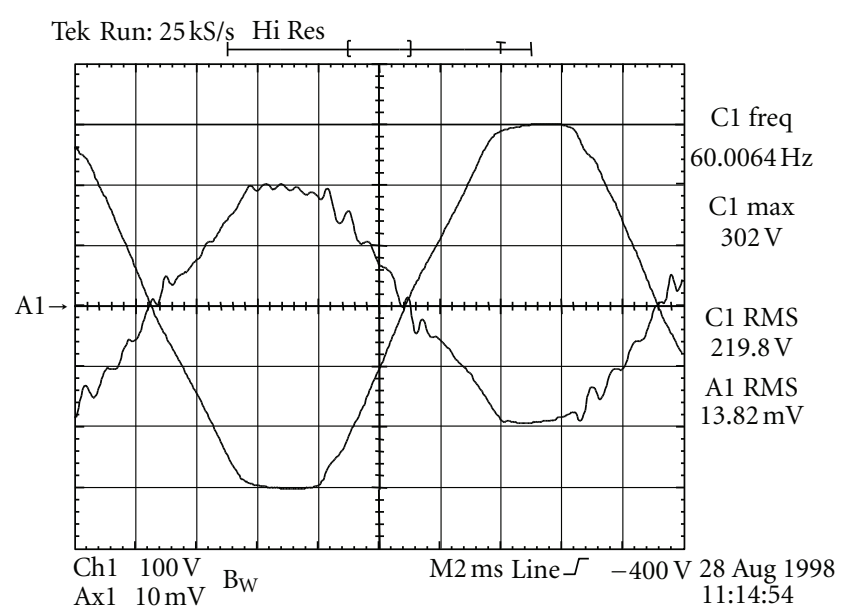

FIGURE 34: Voltage and current in the main power supply (phase a) $-100 \mathrm{~V} /$ div; $4 \mathrm{~A} /$ div; $2 \mathrm{~ms} /$ div.

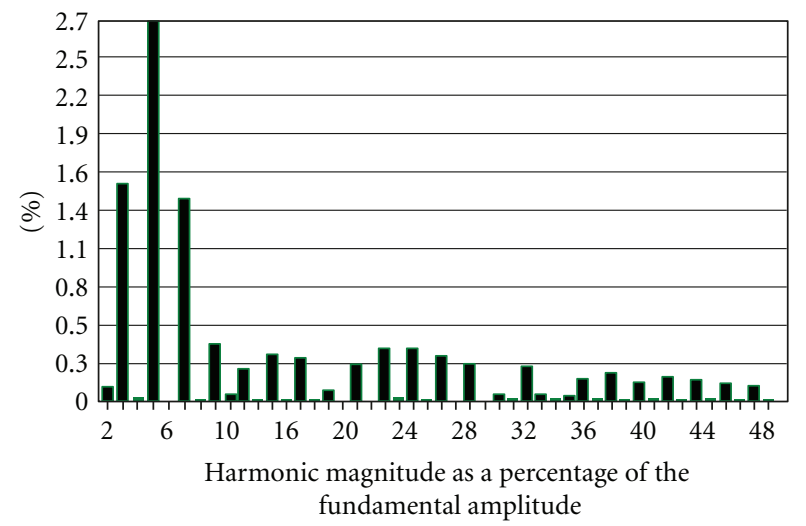

FIGURE 35: Voltage harmonic analysis of the main power supply$\mathrm{THD}=3.69 \%$.

Figure 37 presents the performance of the utility voltage and utility current (THD of current $4.98 \%$, phase angle = $172^{\circ}$ ), with $32 \%$ of the full power delivery to the grid (around $1300 \mathrm{~W}$ ). For this power conditions, the whole system efficiency is $90 \%$. Below this power the efficiency decreases drastically.

\section{Conclusion}

In this paper, a modified dual-stage inverter applied to grid-connected photovoltaic systems performed for high power applications has been studied. The modified dualstage inverter contains DC-DC stage and DC-AC stage. Through the Behavior Matching, the DC-DC stage operates with constant frequency and duty cycle and the DC-AC stage becomes responsible for the maximum power point tracking and grid-current control. $I-V$ characteristic of the PV array was reproduced in the output of the DC-DC stage, without any control, which was defined as Behavior Matching. Some sensors could be avoided because the grid-current control apparatus produces the variables needed for the MPPT. In addition, only one digital controller can generate gate pulses 


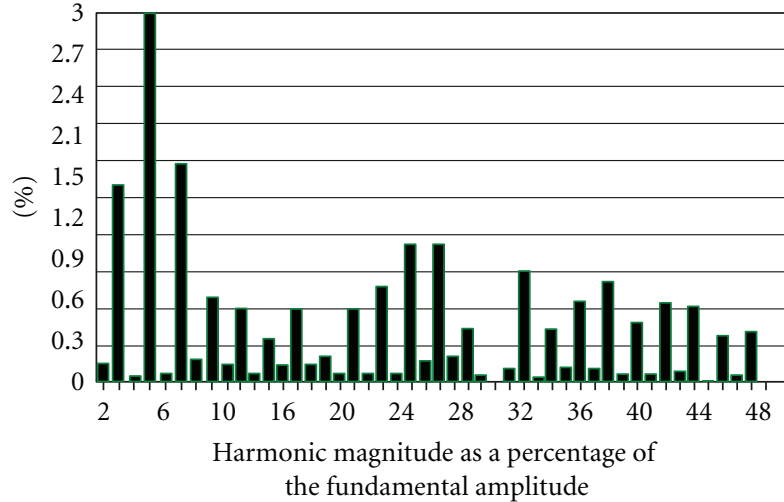

FIGURE 36: Current harmonic analysis of the main power supply$\mathrm{THD}=4.89 \%$, phase angle $=-175^{\circ}$.

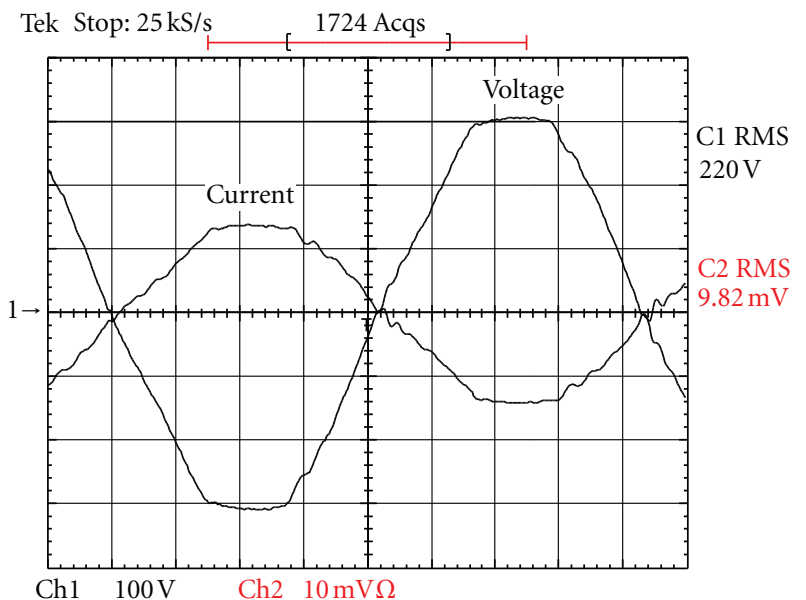

FIGURE 37: Utility voltage and utility current with $32 \%$ of the full power- $100 \mathrm{~V} /$ div; $2 \mathrm{~A} /$ div; $2 \mathrm{~ms} /$ div.

for all transistors of the PV system, which results in simpler and cheaper topology. The Behavior Matching technique allows the construction of the Modified Dual-Stage Inverter.

The three-phase DC-DC series resonant converter switching with constant frequency keeps the structure operating with the maximum efficiency and optimized transformer utilization. The topologies chosen for the converters qualify the modified dual-stage inverter for high power operation. The transformer size can be minimized by the increase of the DC-DC converter switching frequency, which is independent of the DC-AC stage. The filter elements size is also reduced due to the low ripple of DC-DC converter input and output current. As a consequence, an insignificant capacitor was used on implementation of the PV array parallel filter. Two factors mainly contributed with this advantage: the continuous current flux with low ripple and the barrier formed by the resonant circuit to electrical perturbations on DC link that did not affect the primary side voltage bus. Besides, the Series Resonant Converter features a robust operation under unbalanced conditions.

The periodic action of the inverter prevents losses and instability, inherent problems of the $\mathrm{P}$ and $\mathrm{O}$ technique.
When the MPOP is found, the voltage $V_{\mathrm{dc}}$ is clamped, avoiding voltage ripple in the photovoltaic array terminals. Moreover, it can be opted for a small perturbation magnitude, minimizing the steady-state error, since the DC-DC converter is that will response for the fast atmospheric condition changes. As was seen, it possesses an extremely fast dynamics. Although $\mathrm{P}$ and $\mathrm{O}$ method was used, other techniques are encouraged.

Finally, the author expects that the efficiency and the implementation simplicity of the whole system are advantages that promote its use.

\section{Acknowledgments}

The author would like to thank the CNPq and FINEP for the financial support.

\section{References}

[1] X. Yuan and Y. Zhang, "Status and opportunities of photovoltaic inverters in grid-tied and micro-grid systems," in Proceedings of the 5th IEEE Power Electronics and Motion Control Conference, pp. 593-596, August 2006.

[2] M. P. Kazmierkowski and L. Malesani, "Current control techniques for three-phase voltage-source pwm converters: a survey," IEEE Transactions on Industrial Electronics, vol. 45, no. 5, pp. 691-703, 1998.

[3] H. M. Kojabadi, B. Yu, I. A. Gadoura, L. Chang, and M. Ghribi, "A novel DSP-based current-controlled PWM strategy for single phase grid connected inverters," IEEE Transactions on Power Electronics, vol. 21, no. 4, pp. 985-993, 2006.

[4] E. N. Costogue and S. Lindena, "Comparison of candidate solar array maximum power utilization approaches," in Proceedings of the Intersociety Energy Conversion Engineering Conference, pp. 1449-1456, 1976.

[5] E. E. Landsman, Maximum Power Point Tracker for Photovoltaic Arrays, Massachusetts Institute of Technology Lincoln Labs, Boston, Mass, USA, 1978.

[6] L. L. Bucciarelli, B. L. Grossman, E. F. Lyon, and N. E. Rasmussen, "The energy balance associated with the use of a MPPT in a $100 \mathrm{~kW}$ peak power system," in Proceedings of the IEEE Photovoltaic Specialists Conference, pp. 523-527, January 1980.

[7] J. J. Schoeman and J. D. van Wyk, "A simplified maximal power controller for terrestrial photovoltaic panel arrays," in Proceedings of the 13th Annual IEEE Power Electronics Specialists Conference, pp. 361-367, 1982.

[8] V. Arcidiacono, S. Corsi, and L. Lambri, "Maximum power point tracker for photovoltaic power plants," in Proceedings of the IEEE Photovoltaic Specialists Conference, pp. 507-512, 1982.

[9] G. W. Hart, H. M. Branz, and C. H. Cox, "Experimental tests of open-loop maximum-power-point tracking techniques for photovoltaic arrays," Solar Cells, vol. 13, no. 2, pp. 185-195, 1984.

[10] M. J. Case and J. J. Schoeman, "A minimum component photovoltaic array maximum power point tracker," in Proceedings of the European Space Power Conference, pp. 107-110, August 1993.

[11] D. C. Martins, C. L. Weber, and R. Demonti, "Photovoltaic power processing with high efficiency using maximum power 
ratio technique," in Proceedings of the 28th IEEE Annual Conference of the Industrial Electronics Society (IECON '02), vol. 1, pp. 368-372, November 2002.

[12] D. C. Martins, A. S. de Andrade, A. Bottion, D. P. da Silva, and K. C. A. de Souza, "PV solar energy electronics processing system operating at the MPP for commercial refrigerator supply applications," in Proceedings of the IEEE Annual Power Electronics Specialists Conference (IEEE-PESC '05), vol. 1, pp. 217-223, 2005.

[13] M. A. El-Shibini and H. H. Rakha, "Maximum power point tracking technique," in Proceedings of Integrating Research, Industry and Education in Energy and Communication Engineering Electrotechnical Conference (MELECON '89), pp. 21-24, April 1989.

[14] D. Shmilovitz, "On the control of photovoltaic maximum power point tracker via output parameters," IEE Proceedings: Electric Power Applications, vol. 152, no. 2, pp. 239-248, 2005.

[15] N. Femia, G. Petrone, G. Spagnuolo, and M. Vitelli, “Optimization of perturb and observe maximum power point tracking method," IEEE Transactions on Power Electronics, vol. 20, no. 4, pp. 963-973, 2005.

[16] M. M. Casaro and D. C. Martins, "Application of the threephase series resonant converter in a dual-stage inverter operating without specific sensor to perform the MPPT,' in Proceedings of the 33rd Annual Conference of the IEEE Industrial Electronics Society (IEEE-IECON '07), pp. 1650-1655, November 2007.

[17] R. F. Coelho, F. Concer, and D. C. Martins, "A study of the basic DC-DC converters applied in maximum power point tracking," in Proceedings of the Brazilian Power Electronics Conference (COBEP '09), pp. 673-678, October 2009.

[18] T. Esram and P. L. Chapman, "Comparison of photovoltaic array maximum power point tracking techniques," IEEE Transactions on Energy Conversion, vol. 22, no. 2, pp. 439-449, 2007.

[19] M. A. G. de Brito, L. G. Junior, L. P. Sampaio, G. A. e Melo, and C. A. Canesin, "Main maximum Power point tracking strategies intended for photovoltaic," in Proceedings of the Brazilian Power Electronics Conference (COBEP '11), pp. 524-530, 2011.

[20] R. F. Coelho, F. M. Concer, and D. C. Martins, "A simplified analysis of DC-DC converters applied as maximum power point tracker in photovoltaic systems," in Proceedings of the 2nd IEEE International Symposium on Power Electronics for Distributed Generation Systems (PEDG '10), pp. 29-34, June 2010.

[21] R. F. Coelho, F. M. Concer, and D. C. Martins, "A MPPT approach based on temperature measurements applied in PV systems," in Proceedings of the IEEE International Conference on Sustainable Energy Technologies (ICSET '10), December 2010.

[22] M. C. Cavalcanti, K. C. Oliveira, G. M. S. Azevedo, and F. A. S. Neves, "Comparative study of maximum power point tracking techniques for photovoltaic systems," Brazilian Journal of Power Electronics, vol. 12, pp. 163-171, 2007.

[23] R. F. Coelho, F. M. Concer, and D. C. Martins, "Analytical and experimental analysis of DC-DC converters in photovoltaic maximum power point tracking applications," in Proceedings of the 36th Annual Conference of the IEEE Industrial Electronics Society (IEEE-IECON '10), pp. 2778-2783, November 2010.

[24] J. M. Carrasco, L. G. Franquelo, J. T. Bialasiewicz et al., "Powerelectronic systems for the grid integration of renewable energy sources: a survey," IEEE Transactions on Industrial Electronics, vol. 53, no. 4, pp. 1002-1016, 2006.
[25] M. M. Casaro and D. C. Martins, "Electronic processing of the photovoltaic solar energy in grid connected systems," Controle y Automacao, vol. 21, no. 2, pp. 159-172, 2010.

[26] N. Kasa, T. Iida, and L. Chen, "Flyback inverter controlled by sensorless current MPPT for photovoltaic power system," IEEE Transactions on Industrial Electronics, vol. 52, no. 4, pp. 1145-1152, 2005.

[27] Q. Li and P. Wolfs, "A review of the single phase photovoltaic module integrated converter topologies with three different DC link configurations," IEEE Transactions on Power Electronics, vol. 23, no. 3, pp. 1320-1333, 2008.

[28] M. Calais, J. Myrzik, T. Spooner, and V. G. Agelidis, "Inverters for single-phase grid connected photovoltaic systems-an overview," in Proceedings of the 33rd Annual IEEE Power Electronics Specialists Conference (IEEE-PESC '02), pp. 1995-2000, June 2002.

[29] S. B. Kjaer, J. K. Pedersen, and F. Blaabjerg, "Power inverter topologies for photovoltaic modules-a review," in Proceedings of the 37th IEEE Annual Meeting and World Conference on Industrial Applications of Electrical Energy (IAS '02), pp. 782-788, October 2002.

[30] B. Yang, W. Li, Y. Zhao, and X. He, "Design and analysis of a grid-connected photovoltaic power system," IEEE Transactions on Power Electronics, vol. 25, no. 4, pp. 992-1000, 2010.

[31] J. A. Sabaté, V. Vlatkovic, R. B. Ridley, F. C. Lee, and B. H. Cho, "Design considerations for high-voltage high-power fullbridge zero-voltage-switched PWM converter," in Proceedings of the IEEE Applied Power Electronics Conference and Exposition (IEEE-APEC '90), pp. 275-284, 1990.

[32] R. Redl, N. O. Sokal, and L. Balogh, "A novel soft-switching fullbridge DC/DC converter: analysis, design considerations, and experimental results at $1.5 \mathrm{~kW}, 100 \mathrm{kHz}$," IEEE Transactions on Power Electronics, vol. 6, no. 3, pp. 408-418, 1991.

[33] R. Redl, L. Balogh, and D. W. Edwards, "Optimum ZVS full-bridge DC/DC converter with PWM phase-shift control analysis design considerations, and the experimental results," in Proceedings of the 9th Annual IEEE Applied Power Electronics Conference and Exposition, vol. 1, pp. 159-165, February 1994.

[34] K. C. A. de Souza, O. H. Gonçalves, and D. C. Martins, "Study and optimization of two dc-dc power structures used in a gridconnected photovoltaic system," in Proceedings of the 37th IEEE Power Electronics Specialists Conference (IEEE-PESC '06), pp. 1-5, June 2006.

[35] P. F. Kocybik and K. N. Bateson, "Digital control of a ZVS fullbridge DC-DC converter," in Proceedings of the 10th Annual IEEE Applied Power Electronics Conference, vol. 2, pp. 687-693, March 1995.

[36] Y. Jang and M. M. Jovanović, "A new family of full-bridge ZVS converters," IEEE Transactions on Power Electronics, vol. 19, no. 3, pp. 701-708, 2004.

[37] K. C. A. de Souza, W. M. dos Santos, and D. C. Martins, "A single-phase active power filter based in a two stages grid-connected PV system," in Proceedings of the 35th Annual Conference of the IEEE Industrial Electronics Society (IEEEIECON '09), pp. 114-119, November 2009.

[38] K. C. A. de Souza, W. M. dos Santos, and D. C. Martins, "Active and reactive power control in a single-phase gridconnected PV system with optimization of the ferrite core volume," International Review of Electrical Engineering, vol. 6, no. 7, pp. 3142-3151, 2011.

[39] J. P. Lee, B. D. Min, T. J. Kim, D. W. Yoo, and J. Y. Yoo, "A novel topology for photovoltaic DC/DC full-bridge converter with 
flat efficiency under wide PV module voltage and load range," IEEE Transactions on Industrial Electronics, vol. 55, no. 7, pp. 2655-2663, 2008.

[40] P. D. Ziogas, A. R. Prasad, and S. Manias, "Analysis and design of a three-phase off-line DC/DC converter with high frequency isolation," in Proceedings of the IEEE Conference Record of the Industry Applications Society Annual Meeting (IAS '88), pp. 813-820, 1988.

[41] R. W. A. A. de Doncker, D. M. Divan, and M. H. Kheraluwala, "A three-phase soft-switched high-power-density DC/DC converter for high-power applications," IEEE Transactions on Industry Applications, vol. 27, no. 1, pp. 63-73, 1991.

[42] J. Jacobs, A. Averberg, and R. de Doncker, "A novel three-phase DC/DC converter for high-power applications," in Proceedings of the IEEE 35th Annual Power Electronics Specialists Conference (PESC '04), pp. 1861-1867, June 2004.

[43] M. M. Casaro and D. C. Martins, "Application of the threephase series resonant converter in a dual-stage inverter operating without specific sensor to perform the MPPT,' in Proceedings of the 33rd Annual Conference of the IEEE Industrial Electronics Society, pp. 1650-1655, November 2007.

[44] M. M. Casaro and D. C. Martins, "Grid-connected PV system: introduction to behavior matching," in Proceedings of the 39th Annual IEEE Power Electronics Specialists Conference, pp. 951-956, June 2008.

[45] M. M. Casaro and D. C. Martins, "Paths to sustainable energy," in PV Solar Energy Conversion Using the Behavior Matching Technique, J. Nathwani and A. W. Ng, Eds., chapter 11, pp. 199-210, InTech, Vienna, Austria, 2010.

[46] S. B. Kjaer, J. K. Pedersen, and F. Blaabjerg, "A review of single-phase grid-connected inverters for photovoltaic modules," IEEE Transactions on Industry Applications, vol. 41, no. 5, pp. 1292-1306, 2005.

[47] J. Li, F. Zhuo, J. Liu et al., "Study on unified control of gridconnected generation and harmonic compensation in dualstage high-capacity PV system," in Proceedings of the IEEE Energy Conversion Congress and Exposition (IEEE-ECCE '09), pp. 3336-3342, September 2009.

[48] M. M. Casaro and D. C. Martins, "Architectural and control contributions for PV grid-connected systems applying dualstage inverters," in Proceedings of the 14th IEEE International Conference on Electronics, Circuits and Systems (IEEE-ICECS '07), pp. 861-864, December 2007.

[49] N. Femia, G. Petrone, G. Spagnuolo, and M. Vitelli, "A technique for improving $\mathrm{P} \& \mathrm{O}$ MPPT performances of double-stage grid-connected photovoltaic systems," IEEE Transactions on Industrial Electronics, vol. 56, no. 11, pp. 4473-4482, 2009.

[50] D. Cruz Martins and R. Demonti, "Grid connected PV system using two energy processing stages," in Proceedings of the 29th IEEE Photovoltaic Specialists Conference, pp. 1649-1652, May 2002.

[51] M. M. Casaro and D. C. Martins, "Behavior Matching as fundamental feature to obtain a modified dual-stage inverter," in Proceedings of the IEEE International Symposium on Industrial Electronics (ISIE '08), pp. 2426-2431, July 2008.

[52] M. M. Casaro and D. C. Martins, "Grid-connected PV system using a three-phase modified dual-stage inverter," in Proceedings of the Brazilian Power Electronics Conference (COBEP '09), pp. 167-173, October 2009.

[53] G. Petrone, G. Spagnuolo, and M. Vitelli, "A multivariable perturb-and-observe maximum power point tracking technique applied to a single-stage photovoltaic inverter," IEEE
Transactions on Industrial Electronics, vol. 58, no. 1, pp. 76-84, 2011.

[54] A. Nasr, A. Ali, M. H. Saied, M. Z. Mostafa, and T. M. AbdelMoneim, "A survey of maximum ppt technique of PV systems," in Proceedings of the IEEE Energy Tech, May 2012.

[55] F. Liu, Y. Kang, Y. Zhang, and S. Duan, "Comparison of $\mathrm{P} \& \mathrm{O}$ and hill climbing MPPT methods for grid-connected PV converter," in Proceedings of the 3rd IEEE Conference on Industrial Electronics and Applications (IEEE-ICIEA '08), pp. 804-807, June 2008.

[56] N. Femia, G. Petrone, G. Spagnuolo, and M. Vitelli, “Optimizing duty-cycle perturbation of $\mathrm{P} \& \mathrm{O}$ MPPT technique," in Proceedings of the 35th Annual IEEE Power Electronics Specialists Conference (IEEE-PESC '04), vol. 3, pp. 1939-1944, June 2004.

[57] G. M. S. Azevedo, M. C. Cavalcanti, K. C. Oliveira, F. A. S. Neves, and Z. D. Lins, "Evaluation of maximum power point tracking methods for grid connected photovoltaic systems," in Proceedings of the 39th Annual IEEE Power Electronics Specialists Conference, pp. 1456-1462, June 2008.

[58] J. S. Kumari, D. C. S. Babu, and A. K. Babu, "Design and analysis of P\&O and IP\&O MPPT technique for photovoltaic system," International Journal of Modern Engineering Research, vol. 2, no. 4, pp. 2174-2180, 2012.

[59] S. Campbell and H. A. Toliyat, "DSP-based electromechanical motion control," in Clarke's and Park's Transformations, Chapter 10, pp. 209-222, CRC Press, 2003.

[60] M. F. Schonardie and D. C. Martins, "Application of the dq0 transformation in the three-phase grid-connected PV systems with active and reactive power control," in Proceedings of the Annual IEEE International Conference on Sustainable Energy Technologies (IEEE-ICSET '08), pp. 18-23, November 2008.

[61] W. Xiao, M. G. J. Lind, W. G. Dunford, and A. Capel, "Real-time identification of optimal operating points in photovoltaic power systems," IEEE Transactions on Industrial Electronics, vol. 53, no. 4, pp. 1017-1026, 2006.

[62] Y. Tsuno, Y. Hishikawa, and K. Kurokawa, "Temperature and irradiance dependence of the I-V curves of various kinds of solar cells," in Proceedings of the 15th International Photovoltaic Science \& Engineering Conference (PVSEC '05), pp. 422-423, 2005.

[63] M. G. Villalva, J. R. Gazoli, and E. R. Filho, "Comprehensive approach to modeling and simulation of photovoltaic arrays," IEEE Transactions on Power Electronics, vol. 24, no. 5, pp. 1198-1208, 2009.

[64] R. F. Coelho, F. M. Concer, and D. C. Martins, "A proposed photovoltaic module and array mathematical modeling destined to simulation," in Proceedings of the IEEE International Symposium on Industrial Electronics (IEEE-ISIE '09), pp. 1624-1629, July 2009.

[65] J. A. R. Hernanz, J. J. C. Martin, I. Z. Belver, J. L. Lesaka, E. Z. Guerrero, and E. P. Perez, "Modelling of photovoltaic module," in Proceedings of the International Conference on Renewable Energy an Power Quality, 2010.

[66] K. H. Hussein, I. Muta, T. Hoshino, and M. Osakada, "Maximum photovoltaic power tracking: an algorithm for rapidly changing atmospheric conditions," IEE Proceedings: Generation, Transmission and Distribution, vol. 142, no. 1, pp. 59-64, 1995.

[67] N. Mutoh, M. Ohno, and T. Inoue, "A method for MPPT control while searching for parameters corresponding to weather conditions for PV generation systems," IEEE Transactions on Industrial Electronics, vol. 53, no. 4, pp. 1055-1065, 2006. 
[68] J. A. Gow and C. D. Manning, "Development of a photovoltaic array model for use in power-electronics simulation studies," IEE Proceedings on Electric Power Applications, vol. 146, no. 2, pp. 193-200, 1999.

[69] C. Hua, J. Lin, and C. Shen, "Implementation of a DSPcontrolled photovoltaic system with peak power tracking," IEEE Transactions on Industrial Electronics, vol. 45, no. 1, pp. 99-107, 1998.

[70] A. R. Prasad, P. D. Ziogas, and S. Manias, "A three-phase resonant PWM DC-DC converter," in Proceedings of the 22nd Annual IEEE Power Electronics Specialists Conference (PESC '91), pp. 463-473, June 1991.

[71] A. K. S. Bhat and L. Zheng, "Analysis and design of a threephase LCC-type resonant converter," in Proceedings of the 27th Annual IEEE Power Electronics Specialists Conference, pp. 252-258, January 1996.

[72] D. S. Oliveira Jr. and I. Barbi, "A three-phase ZVS PWM DC/DC converter with asymmetrical duty cycle associated with a threephase version of the hybridge rectifier," IEEE Transactions on Power Electronics, vol. 20, no. 2, pp. 354-360, 2005.

[73] M. M. Casaro, Modified dual-stages three-phase inverter applied in the photovoltaic solar energy processing in grid-connected systems [Ph.D. thesis], Federal University of Santa Catarina, Santa Catarina, Brazil, 2009.

[74] M. M. Casaro and D. C. Martins, "Behavior matching technique applied to a three-phase grid-connected PV system," in Prroceedings of the IEEE International Conference on Sustainable Energy Technologies (ICSET '08), pp. 12-17, November 2008.

[75] F. Blaabjerg, R. Teodorescu, Z. Chen, and M. Liserre, "Power converters and control of renewable energy systems," in Proceedings of the International Conference on Performance Engineering (ICPE '04), pp. I2-I20, 2004.

[76] J. Selvaraj and N. A. Rahim, "Multilevel inverter for gridconnected PV system employing digital PI controller," IEEE Transactions on Industrial Electronics, vol. 56, no. 1, pp. 149-158, 2009.

[77] D. G. Holmes, “The general relationship between regularsampled pulse-width-modulation and space vector modulation for hard switched converter," in Proceedings of the IEEE Conference Record of the Industry Applications Society Annual Meeting (IEEE-IAS '92), pp. 1002-1009, 1992.

[78] F. Blaabjerg, S. Freysson, H. H. Hansen, and S. Hansen, "New optimized space vector modulation strategy for a component minimized voltage source inverter," in Proceedings of the 10th Annual IEEE Applied Power Electronics Conference (APEC '95), pp. 577-585, March 1995.

[79] T. Halkosaari and H. Tuusa, "Optimal vector modulation of a pwm current source converter according to minimal switching losses," IEEE Power Electronics Specialists Conference, pp. 127-132, 2000.

[80] K. Zhou and D. Wang, "Relationship between space-vector modulation and three-phase carrier-based PWM: a comprehensive analysis," IEEE Transactions on Industrial Electronics, vol. 49, no. 1, pp. 186-196, 2002.

[81] F. A. B. Batista and I. Barbi, "Space vector modulation applied to three-phase three-switch two-level unidirectional PWM rectifier," IEEE Transactions on Power Electronics, vol. 22, no. 6, pp. 2245-2252, 2007.

[82] A. Lega, M. Mengoni, G. Serra, A. Tani, and L. Zarri, "General theory of space vector modulation for five-phase inverters," in Proceedings of the IEEE International Symposium on Industrial Electronics (ISIE '08), pp. 237-244, July 2008.
[83] M. H. Rashid, Power Electronics Handbook, Academic Press, New York, NY, USA, 2001.

[84] Y. Jung, J. So, G. Yu, and J. Choi, "Improved perturbation and observation method (IP\&O) of MPPT control for photovoltaic power systems," in Proceedings of the 31st IEEE Photovoltaic Specialists Conference, pp. 1788-1791, January 2005.

[85] W. J. A. Teulings, J. C. Marpinard, A. Capel, and D. O’Solluivan, "New maximum power point tracking system," in Proceedings of the 24th Annual IEEE Power Electronics Specialist Conference, pp. 833-838, June 1993.

[86] P. Midya, P. T. Krein, R. J. Turnbull, R. Reppa, and J. Kimball, "Dynamic maximum power point tracker for photovoltaic applications," in Proceedings of the 27th Annual IEEE Power Electronics Specialists Conference, pp. 1710-1716, January 1996.

[87] Y. C. Kuo, T. J. Liang, and J. F. Chen, "Novel maximum-powerpoint-tracking controller for photovoltaic energy conversion system," IEEE Transactions on Industrial Electronics, vol. 48, no. 3, pp. 594-601, 2001.

[88] T. Y. Kim, H. G. Ahn, S. K. Park, and Y. K. Lee, "A novel maximum power point tracking control for photovoltaic power system under rapidly changing solar radiation," in Proceedings of the IEEE International Symposium on Industrial Electronics Proceedings (ISIE '01), pp. 1011-1014, June 2001.

[89] X. Liu and L. A. C. Lopes, "An improved perturbation and observation maximum power point tracking algorithm for PV arrays," in Proceedings of the 35th Annual IEEE Power Electronics Specialists Conference, pp. 2005-2010, June 2004.

[90] C. Dorofte, U. Borup, and F. Blaabjerg, "A combined twomethod MPPT control scheme for grid-connected photovoltaic systems," in Proceedings of the European Conference on Power Electronics and Applications, pp. 1-10, September 2005.

[91] C. Jaen, C. Moyano, X. Santacruz, J. Pou, and A. Arias, "Overview of maximum power point tracking control techniques used in photovoltaic systems," in Proceedings of the 15th IEEE International Conference on Electronics, Circuits and Systems (IEEE-ICECS '08), pp. 1099-1102, September 2008.

[92] R. Faranda, S. Leva, and V. Maugeri, "MPPT techniques for PV systems: energetic and cost comparison," in Proceedings of the IEEE Power and Energy Society General Meeting-Conversion and Delivery of Electrical Energy in the 21st Century, pp. 1-6, Pittsburgh, Pa, USA, July 2008.

[93] J. Lopez-Seguel, S. I. Seleme, P. Donoso-Garcia, L. F. Morais, P. Cortizo, and M. S. Mendes, "Comparison of MPPT approaches in autonomous photovoltaic energy supply system using DSP," in Proceedings of the IEEE International Conference on Industrial Technology (IEEE-ICIT '10), pp. 1149-1154, March 2010.

[94] V. V. R. Scarpa, G. Spiazzi, and S. Buso, "Low complexity MPPT technique exploiting the effect of the PV cell series resistance," in Proceedings of the 23rd Annual IEEE Applied Power Electronics Conference and Exposition (IEEE-APEC '08), pp. 1958-1964, February 2008.

[95] N. Femia, G. Petrone, G. Spagnuolo, and M. Vitelli, "Optimizing sampling rate of $\mathrm{P} \& \mathrm{O}$ MPPT technique," in Proceedings of the 35th Annual IEEE Power Electronics Specialists Conference (PESC '04), pp. 1945-1949, June 2004.

[96] M. M. Casaro and D. C. Martins, "New method of MPPT application for dual-stage inverters," in Proceedings of the Brazilian Power Electronics Conference, pp. 676-681, 2007.

[97] H. F. M. Lopez, R. C. Viero, C. Zollmann et al., "Analog signal processing for photovoltaic panels grid-tied by Zeta converter," in Proceedings of the IEEE Electrical Power and Energy Conference (IEEE-EPEC '09), pp. 1-6, October 2009. 
[98] D. C. Martins and R. Demonti, "Interconnection of a photovoltaic panels array to a single-phase utility line from a static conversion system," in Proceedings of the 31st Annual IEEE Power Electronics Specialists Conference, vol. 3, pp. 1207-1211, 2000.

[99] D. Cruz Martins and R. Demonti, "Photovoltaic energy processing for utility connected system," in Proceedings of the 27th Annual Conference of the IEEE Industrial Electronics Society (IEEE-IECON '01), vol. 2, pp. 1292-1296, December 2001.

[100] S. B. Kjaer, J. K. Pedersen, and F. Blaabjerg, "Power inverter topologies for photovoltaic modules-a review," in Proceedings of the 37th IEEE Conference Record of the Industry Applications Society Annual Meeting (IEEE-IAS '02), vol. 2, pp. 782-788, October 2002.

[101] D. C. Martins, R. Demonti, and R. Rütter, "Analysis of utility interactive photovoltaic generation system using a single power static inverter," in Proceeding of the 28th IEEE Photovoltaic Specialists Conference (IEEE-PVSC '00), pp. 1719-1722, 2000.

[102] D. Borgonovo, Modeling and Control of three-phase PWM rectifiers using the park transformation [M.S. thesis], Federal University of Santa Catarina, Florianópolis, Brazil, 2001. 


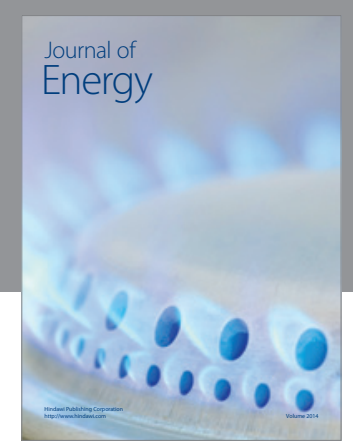

Journal of

Industrial Engineering
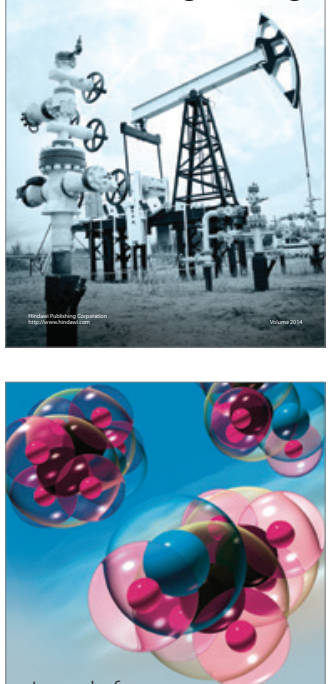

Fuels
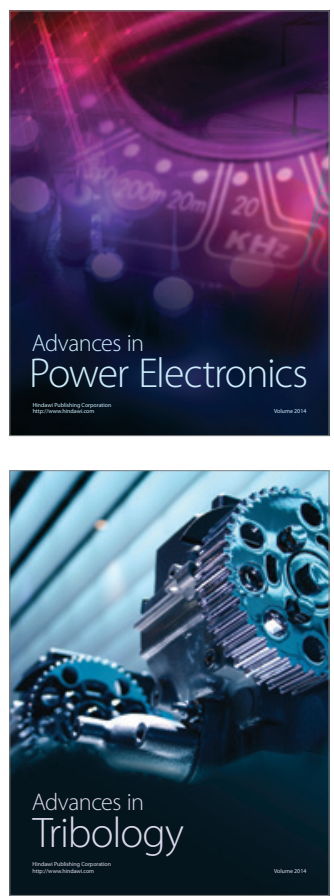

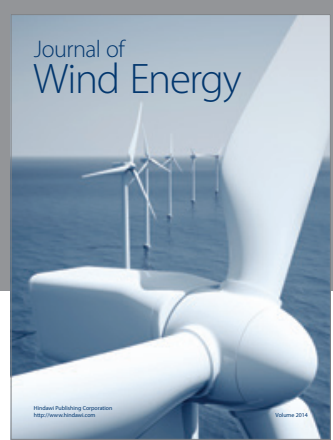

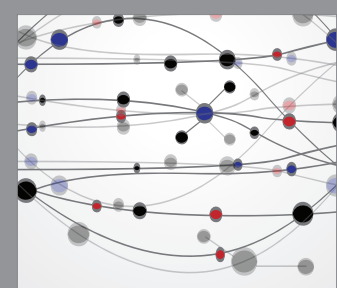

The Scientific World Journal

Submit your manuscripts at http://www.hindawi.com

Journal of

Structures
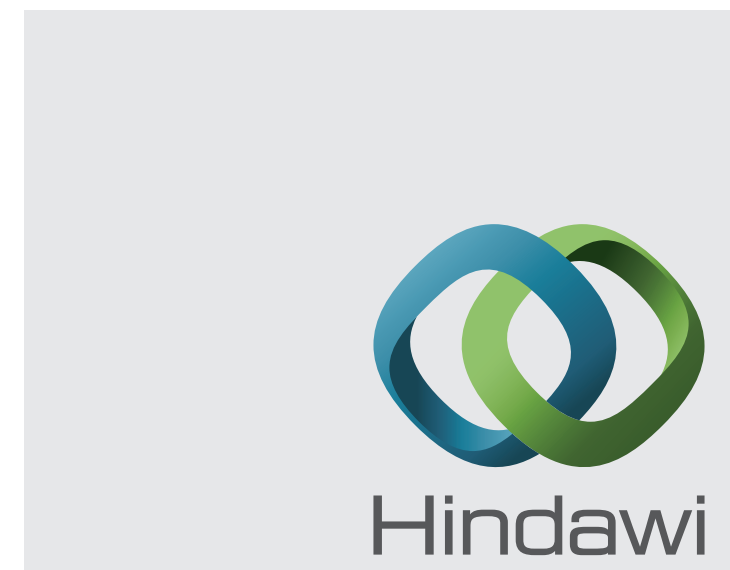

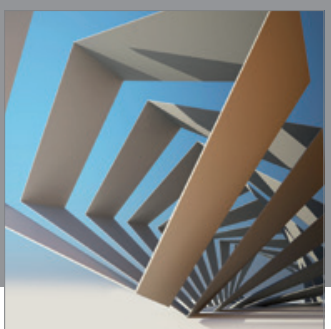

Rotating

Machinery
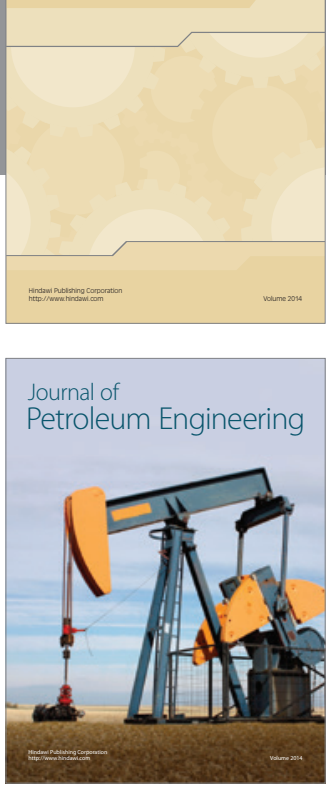

Journal of

Solar Energy
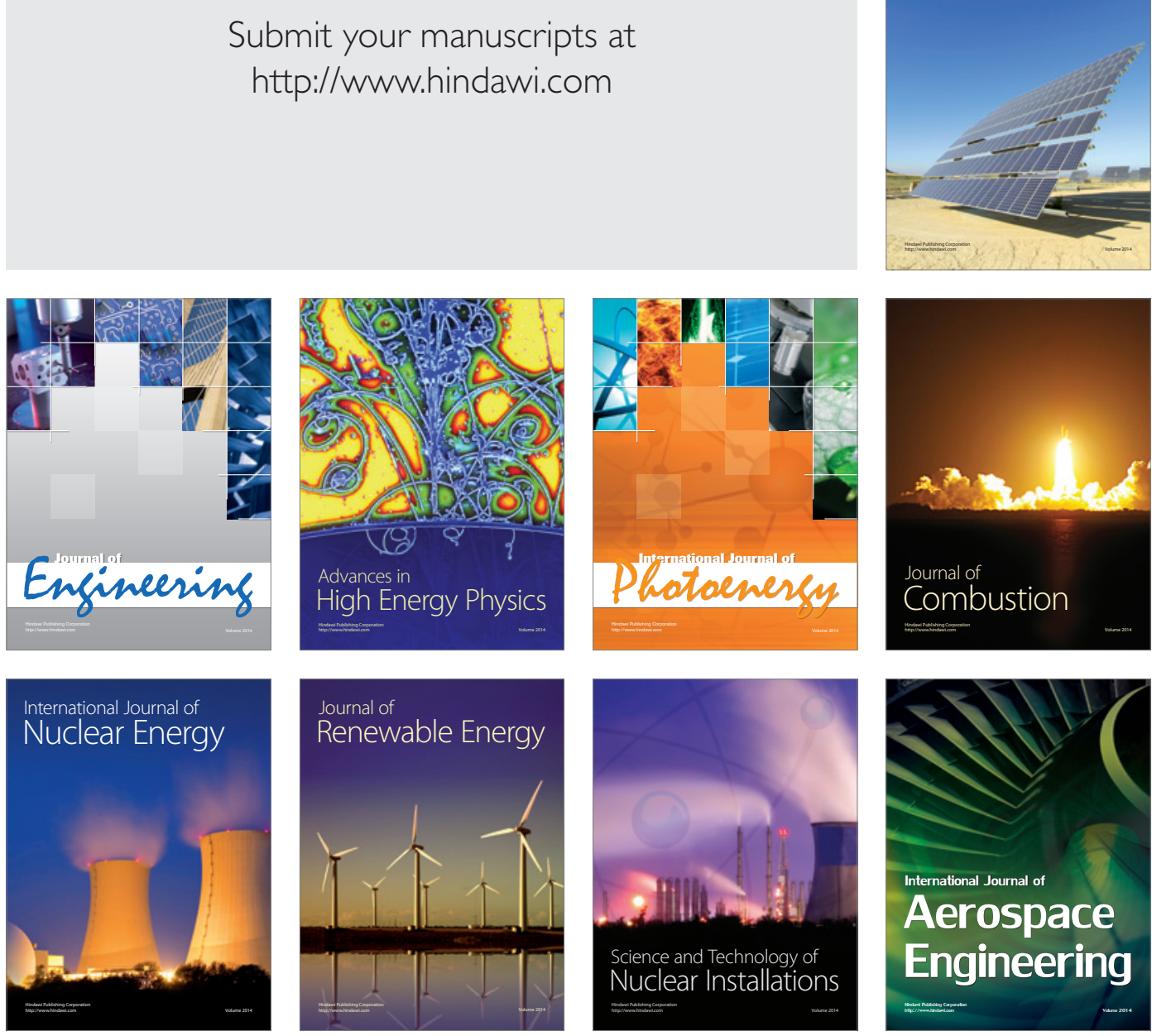